\title{
Observed mean sea level changes around the North Sea coastline from 1800 to present
}

Wahl T. ${ }^{1,2}$, Haigh I. ${ }^{3,4}$, Woodworth P.L ${ }^{5}$, Albrecht F. ${ }^{6}$, Dillingh D. ${ }^{7}$, Jensen J. ${ }^{1}$, Nicholls R.J. ${ }^{8}$, Weisse R. ${ }^{6}$, Wöppelmann G. ${ }^{9}$

${ }^{1}$ Research Institute for Water and Environment, University of Siegen, Paul-Bonatz-Str. 9-11, 57076 Siegen, Germany, email: thomas.wahl@uni-siegen.de, (corresponding author)

${ }^{2}$ Institute of Advanced Studies - FoKoS (Research Group for Civil Security), University of Siegen, Siegen, Germany

${ }^{3}$ National Oceanography Centre, Southampton, United Kingdom

${ }^{4}$ The UWA Oceans Institute and School of Environmental Systems Engineering, University of Western Australia, Perth, Australia

${ }^{5}$ National Oceanography Centre, Liverpool, United Kingdom

${ }^{6}$ Institute for Coastal Research, Helmholtz-Zentrum Geesthacht, Geesthacht, Germany

${ }^{7}$ Deltares, Delft, Netherlands

${ }^{8}$ Faculty of Engineering and the Environment, University of Southampton, Southampton, United Kingdom

${ }^{9}$ LIENSS, UMR7266, Universite de La Rochelle, La Rochelle, France

How to cite: Wahl, T., Haigh, I., Albrecht, F., Dillingh, D., Jensen, J., Nicholls, R., Weisse, R., Woodworth, P.L., Wöppelmann, G. (2013): Observed mean sea level changes around the North Sea coastline from 1800 to present, Earth Science Reviews, 124, 51-67. 


\begin{abstract}
This paper assesses historic changes in mean sea level around the coastline of the North Sea, one of the most densely populated coasts in the world. Typically, such analyses have been conducted at a national level, and detailed geographically wider analyses have not been undertaken for about 20 years. We analyse long records (up to 200 years) from 30 tide gauge sites, which are reasonably uniformly distributed along the coastline, and: (1) calculate relative sea level trends; (2) examine the inter-annual and decadal variations; (3) estimate regional geocentric (sometimes also referred to as 'absolute') sea level rise throughout the $20^{\text {th }}$ century; and (4) assess the evidence for regional acceleration of sea-level rise. Relative sea level changes are broadly consistent with known vertical land movement patterns. The inter-annual and decadal variability is partly coherent across the region, but with some differences between the Inner North Sea and the English Channel. Data sets from various sources are used to provide estimates of the geocentric sea level changes. The long-term geocentric mean sea level trend for the 1900 to 2011 period is estimated to be $1.5 \pm 0.1 \mathrm{~mm} / \mathrm{yr}$ for the entire North Sea region. The trend is slightly higher for the Inner North Sea (i.e. $1.6 \pm$ $0.1 \mathrm{~mm} / \mathrm{yr}$ ), and smaller but not significantly different on the $95 \%$ confidence level for the English Channel (i.e. $1.2 \pm 0.1 \mathrm{~mm} / \mathrm{yr}$ ). The uncertainties in the estimates of vertical land movement rates are still large, and the results from a broad range of approaches for determining these rates are not consistent. Periods of sea level rise acceleration are detected at different times throughout the last 200 years and are to some extent related to air pressure variations. The recent rates of sea level rise (i.e. over the last two to three decades) are high compared to the long-term average, but are comparable to those which have been observed at other times in the late $19^{\text {th }}$ and $20^{\text {th }}$ century.
\end{abstract}

Key words: mean sea level changes; tide gauges; vertical land movement; North Sea; English Channel 


\section{Introduction}

Sea level change is an important scientific topic, particularly as there is concern about rising sea levels and the significant impact this could have on growing coastal communities (Nicholls and Cazenave, 2010). Over the last 130 years, global sea levels have on average risen by about $21 \mathrm{~cm}$ (Church and White, 2011) and it is projected that this rise will continue throughout the $21^{\text {st }}$ century (and beyond) at an accelerated rate (Meehl et al., 2007). The Intergovernmental Panel on Climate Change's (IPCC) Fourth Assessment Report (AR4) considered six marker emission scenarios and projected that global sea levels would rise by between 18 and $59 \mathrm{~cm}$ (depending on the scenario) by 2090 to 2099 relative to 1980 to 1999 . These estimates exclude uncertainties from the large ice sheets. To illustrate this effect, a scaled-up ice sheet imbalance could add up to $20 \mathrm{~cm}$ of sea level rise (SLR) depending on the emission scenario and hence up to $79 \mathrm{~cm}$ SLR is possible according to Meehl et al. (2007). Since publication of the AR4 in 2007, several authors suggested that uncertainty was larger and that a global SLR between 100 to $200 \mathrm{~cm}$ is plausible by 2100 (e.g. Rahmstorf, 2007; Pfeffer et al., 2008; Rohling et al., 2008; Vellinga et al., 2008; Grinsted et al., 2009; Vermeer and Rahmstorf, 2009).

Much of the focus on sea level research has been on determining global mean geocentric rates of change (i.e. changes in the sea surface relative to the centre of the Earth, sometimes also referred to as 'absolute' changes) and to date most coastal risk assessments have been undertaken using global-average projections of geocentric SLR. However, from a coastal management and planning perspective, it is regional or local relative sea level changes (i.e. changes relative to the level of the land) that are important (Nicholls et al., 2011). High quality satellite altimeters have provided a quasi-global measurement of sea level since 1992, and it is clear from this dataset that regional geocentric changes in sea level can differ significantly from the global average rates of rise, due to regional meteorological and oceanographic effects (Church and White, 2011). In the altimeter record, estimated local rates varied from about -10 to $+10 \mathrm{~mm} / \mathrm{yr}$ (e.g. Milne et al., 2009) compared to the global trend of about $3 \mathrm{~mm} / \mathrm{yr}$ recorded since 1992 (Church and White, 2011). On a regional and local scale, relative sea level changes can also vary spatially due to variations in vertical land movement which arise from both natural (tectonics, glacial isostatic adjustment (GIA), etc.) and anthropogenic (usually subsidence caused by withdrawal of ground fluids and the drainage of susceptible soils) geological processes (Nicholls et al., 2007). As future rates of relative regional sea level rise are likely to vary from global mean geocentric rates, it is important that 
historic regional changes are analysed accurately to help provide reliable region-specific SLR projections for coastal management and planning purposes.

The North Sea is a shallow continental shelf sea located between Great Britain in the west, the northern European mainland and Scandinavia in the east, and the central European mainland in the south. It opens to the Atlantic Ocean through the Norwegian Sea in the north and via the English Channel to the southwest, and it has a connection to the Baltic Sea in the east. The coastline around the North Sea is one of the most densely populated coastlines in the world with a coastal flood plain population of roughly 15 million people, and including all or parts of four large port cities (populations in excess of 1 million): London, greater Amsterdam, greater Rotterdam and Hamburg (Hanson et al., 2011). The region has a long history of significant coastal flooding (Lamb, 1991). The disastrous storm surge events in 1953 (UK and Dutch coastline) and 1962 (German coastline) in particular, led to the construction of modern coastal protection measures and flood warning systems along major parts of the coastline (e.g., McRobie et al., 2005; Munich Re, 2012). Much of the North Sea coastline is now heavily defended and contains major flood defence structures (e.g. the Thames Barrier in London and the Delta works in the Netherlands), which are part of integrated coastal protection systems. The implications of SLR to the North Sea coastline have been assessed in various papers on a country-wide scale, e.g. by de la Vega-Leinert and Nicholls (2008) for Great Britain, Lebbe et al. (2008) for Belgium, Van Koningsveld et al. (2008) for the Netherlands, Sterr (2008) for Germany, Fenger et al. (2008) for Denmark, Aunan and Romstad (2008) for Norway and Paskoff (2004) for France. Long-term management plans including an allowance for future sea-level rise are being formulated in the region from the scale of critical coastal infrastructure (Wilby et al., 2011) to specific regions (e.g. Lavery and Donovan, 2005) to nations (Stive et al., 2011).

There have been surprisingly few regional-wide studies of MSL changes in the North Sea; most assessments of MSL around the North Sea have tended to be undertaken on a country-by-country basis. The last detailed regional study was by Shennan and Woodworth (1992). They used tide gauge and geological data from sites around the North Sea to infer $20^{\text {th }}$ century and late Holocene secular trends in MSL. They concluded that a systematic offset of $1.0 \pm 0.15 \mathrm{~mm} / \mathrm{yr}$ in the tide gauge trends compared to those derived from the geological data could be interpreted as the regional geocentric rate of MSL change in the $20^{\text {th }}$ century. They also constructed a sea level index to represent the coherent part of sea level variability in the region and found no evidence for a statistically significant acceleration in the rates of SLR over the $20^{\text {th }}$ century. These results were in agreement with those of Woodworth (1990), who 
found a significant acceleration in the order of $0.4 \mathrm{~mm} / \mathrm{yr}$ per century when focusing on time scales longer than a century (up to 300 years) but not for the $20^{\text {th }}$ century.

Several assessments of MSL changes have been undertaken for specific stretches of the North Sea coastline. Major reviews of changes in UK MSL have been conducted on about a decadal basis over the last 30 years (i.e. Woodworth, 1987; Woodworth et al., 1999, 2009a). In the most recent assessment, Woodworth et al. (2009a) estimated that geocentric (or 'absolute') mean sea level (AMSL) around the UK rose by $1.4 \pm 0.2 \mathrm{~mm} / \mathrm{yr}$ over the $20^{\text {th }}$ century. Wahl et al. (2011) considered this to be the best estimate for $20^{\text {th }}$ century sea level changes in the North Sea area, as there was evidence for significant correlation between an updated UK sea level index and long MSL records from other European coastlines (Woodworth et al., 2009a). Araújo (2005), Haigh (2009) and Haigh et al. (2009) analysed MSL records from tide gauge sites around the English Channel. Araújo et al. (2008) and Wöppelmann et al. $(2006,2008)$ considered data sets from single stations (i.e. Newlyn and Brest) to assess long-term sea level changes in the same region. For the Belgian coastline, Van Cauwenberge $(1995,1999)$ and Verwaest et al. (2005) provided estimates of MSL changes based on tide gauge records. Sea level changes along the Dutch coastline have recently been analysed by Dillingh et al. (2010). For the German coastline Wahl et al. (2010, 2011) and Albrecht et al. (2011) conducted the first detailed MSL analyses based on long and high quality tide gauge records. In an earlier study, Jensen et al. (1993) analysed tide gauge records from both the Dutch and the German North Sea coastlines. Observed sea level changes along the Danish coastline were investigated, for example, by Madsen (2009) based on satellite altimetry data (for the period from 1992 to 2008) and 10 tide gauges with record lengths over 100 years (including two tide gauge sites located on the North Sea coast). Richter et al. (2012) analysed the contributions to sea level variability along the Norwegian coast and also provided long-term trend estimates (for the period from 1960 to 2010) derived from tide gauge data sets.

Despite this wealth of analysis, it is difficult to appropriately compare the results because different length, data spans and methods were used to estimate trends. Furthermore, some studies tried to derive estimates for AMSL changes, while others focussed on relative mean sea level (RMSL) changes. In addition, the studies that took vertical land movements into account used estimates from different sources (i.e. GIA models, geological proxy data, continuous Global Positioning System (CGPS)).

With regard to future changes in MSL, regional projections for particular areas of the North Sea have recently been derived for example by Lowe et al. (2009) for the UK, by 
Katsman et al. (2011) for the Dutch coastline, and by Simpson et al. (2012) and Nilsen et al. (2012) for the Norwegian coastline. Slangen et al. (2012) presented maps of $21^{\text {st }}$ century local relative sea level change estimates based on an ensemble of coupled climate model simulations for different emission scenarios. The results suggested that relative sea levels in the North Sea would rise at higher rates (e.g. 0.1 to $0.2 \mathrm{~mm} / \mathrm{yr}$ for the A1B scenario) than the global average, due mainly to GIA effects.

Given that two decades have now passed since the last detailed regional assessment of MSL changes in the North Sea by Shennan and Woodworth (1992), our aim here is to update the results of that previous study using: tide-gauge records that are now 20 years longer across a larger network of sites; altimetry measurements made since 1992; and more precise estimates of vertical land movement made since then with the development of advanced geodetic techniques. In particular we have four main objectives: (i) to calculate up to date and accurate relative sea level trends for common time periods over the last 200 years; (ii) to examine the inter-annual and decadal variations observed in MSL across the region and their spatial coherence; (iii) use a range of different vertical land movement measurements and predictions to provide an updated estimate of AMSL rise throughout the $20^{\text {th }}$ century in the region; and (iv) to assess the evidence for significant accelerations in the rate of SLR and investigate the coherence of the temporal patterns of acceleration/deceleration across the region.

The paper is organised as follows: the investigation area and tide gauge data sets are described in Section 2. The four study objectives are then addressed in Sections 3 to 6, respectively. Finally, conclusions are given in Section 7.

\section{Investigation area and tide gauge data}

Our investigation area is the "Greater North Sea", as defined by the OSPAR commission (Oslo/Paris Convention for the Protection of the Marine Environment of the North-East Atlantic). This is the area which extends from Brest (in north-western France) in the south to the $62^{\circ} \mathrm{N}$ latitude band in the north and from the $5^{\circ} \mathrm{W}$ longitude band in the west to the southwestern coastline of Sweden in the east. However, we do not consider the Kattegat area between Denmark and Sweden, as vertical land movement plays a dominant role in this region and there is a complex interaction between the North and Baltic Sea. Our study area has some of the longest MSL records in the world. We focus on annual MSL values from 30 sites, the locations of which are shown in Fig. 1a. These sites were selected based on the 
length and quality of data, and also to ensure reasonable spatial coverage. Where possible, sites were also selected where the tide gauges are equipped with CGPS. Based on the different criteria there is a greater density of gauges along the south-eastern coastline of the North Sea (i.e. the Belgian, Dutch and German coastlines) and fewer on the UK east coast and in the English Channel. Nevertheless, the selected sites provide a reasonable spatial coverage of the investigation area.

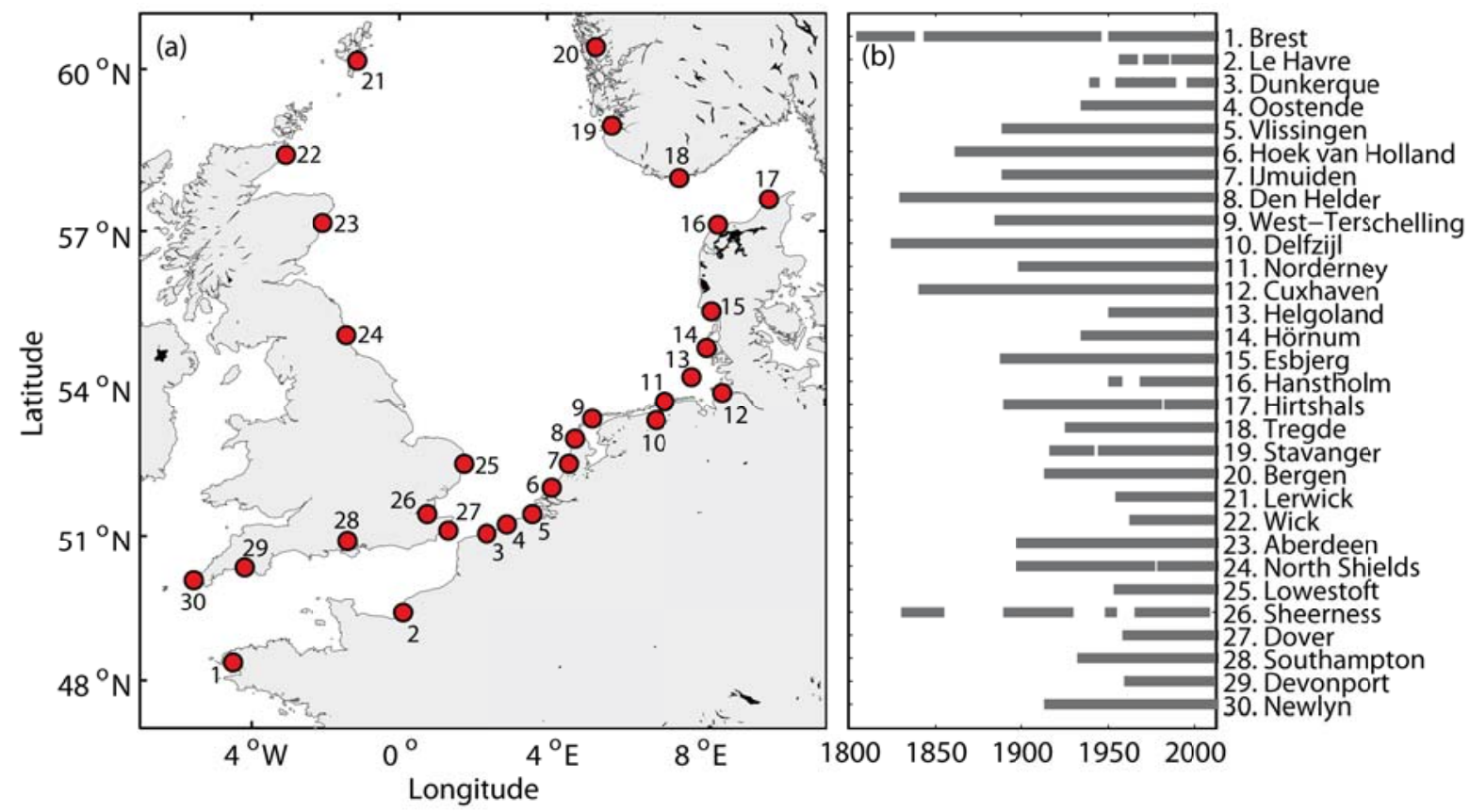

Fig. 1. (a) Locations of the considered tide gauges in the investigation area; (b) duration of the mean sea level data sets.

Annual MSL values were obtained from a variety of sources. The majority of the data was downloaded from the website of the Permanent Service for Mean Sea Level (PSMSL; http://www.psmsl.org/). Only data in the Revised Local Reference (RLR') subset were used for the analyses, as this contains a full benchmark history (Woodworth and Player, 2003). The German dataset was obtained from Wahl et al. (2011) and data for Southampton and Devonport were obtained from Haigh et al. (2009). Annual values from the IJmuiden and Vlissingen records before 1890 were excluded because they are suspect, i.e. they show strong negative trends which are not in agreement with the records from neighbouring sites. In most cases data was available up to 2011; the German and some of the UK data sets (Southampton, Dover and Aberdeen) were updated until 2011 with annual averages calculated from high frequency data sets obtained directly from the relevant authorities. The record from Oostende ends in 2010. 
The durations of the available annual MSL records are shown in Fig. 1b. The longest record available is at Brest, and this starts in 1807. Historical data sets covering several decades in the $18^{\text {th }}$ century are also available (Wöppelmann et al., 2006), but are outside the time period of interest of this study. Several other records start in the early or mid $19^{\text {th }}$ century (e.g. Delfzijl in 1827; Den Helder in 1832; Sheerness in 1833; Cuxhaven in 1843). Almost all of the considered tide gauges provide complete data for the second half of the $20^{\text {th }}$ century (some of the UK records exhibit missing values during the last decade).

\section{Relative Mean Sea Level trends}

The first study objective is to calculate accurate relative sea level trends. Annual RMSL time series for the 30 study sites are shown in Fig. 2. Trends were estimated at each site from these time series using linear regression.
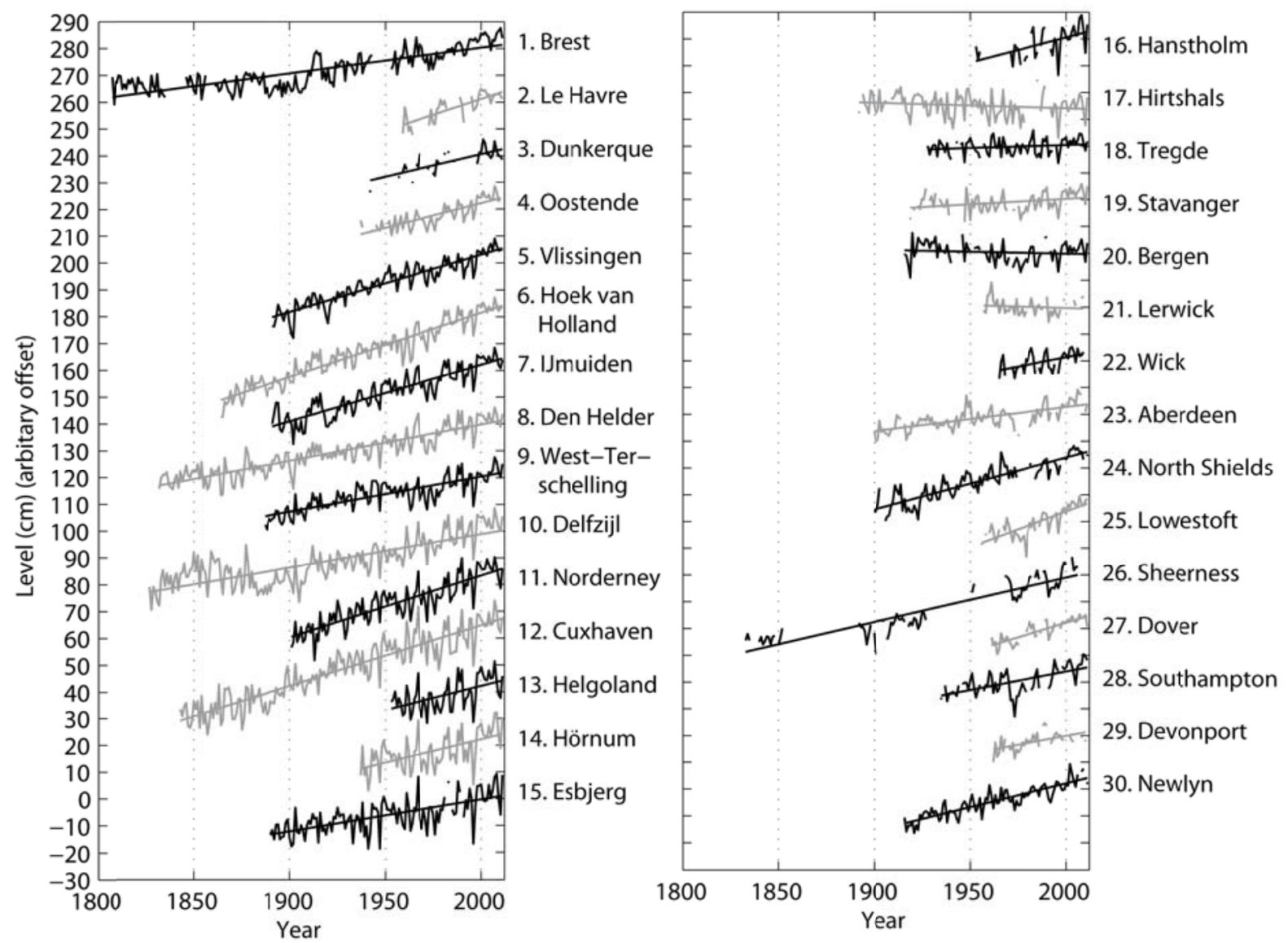

Fig. 2. Annual relative mean sea level time series of the selected tide gauges with linear trends calculated for the entire record lengths and plotted with arbitrary offsets.

In a recent study, Gonzáles et al. (2013) argued that trends calculated directly from annual MSL time series may be influenced by long-term oscillations affecting the sea level 
variability. They suggested filtering the sea level data (i.e. natural oscillations are removed) prior to estimating long-term trends. Applying such an approach, however, requires detailed site specific analyses of the amplitudes of oscillatory components, and this is beyond the scope of this present study. Furthermore, we intend to compare our results with those from earlier studies and hence want to apply the same analysis techniques.

The uncertainties of the trend analyses discussed below are defined as one standard errors (SE) (i.e. 68\% confidence level). If not stated otherwise, SE's derived in the present study consider serial correlation of the underlying sea level time series, i.e. the number of degrees of freedom was reduced as suggested for example by Santer et al. (2000).

In order to compare RMSL changes across the study sites, trends were estimated for five common periods and these are listed in Tab. 1. Trends were only calculated for specific time periods at a particular site when at least $75 \%$ of the data were available for that chosen period. However, there were four exceptions to this rule. At Dunkerque, Lerwick, Sheerness and Devonport trends were determined for the 1993 to 2011 period even though more than $25 \%$ of the data was missing at each site. This was done so that trend estimates were available for each of the 30 sites for the 1993 to 2011 period, i.e. approximately one nodal cycle (18.6 years) and the period of satellite observations.

The trend estimates listed in Tab. 1 indicate a statistically significant (95\% confidence level; i.e. 2 SE) rise in RMSL at many of the study sites for each of the five time periods. The rates of relative change are broadly consistent across the sites for the common time periods given known vertical land movement patterns. Trends are generally lower for the northern British, Danish and Norwegian coastlines which are subject to land uplift (e.g. Hansen et al., 2011; Shennan et al., 2012). Higher trends are derived for the subsiding southern English, Dutch and German coastlines (e.g. Bungenstock and Schäfer, 2009; Shennan and Woodworth, 1992). For each site, the bold values in Tab. 1 represent the highest trends that are derived for the five different time periods. For most of the tide gauges, trends are reasonably consistent for the three longer time periods, while higher values are derived for the two shorter time periods. With the exceptions of Brest, Norderney and Southampton (and the four sites with missing values for the first four time periods) the highest trends are calculated for the 1993 to 2011 period (with the highest value of $6.6 \pm 3.2 \mathrm{~mm} / \mathrm{yr}$ for Hörnum in the north-eastern German Bight). For the shorter periods, the uncertainty estimates are higher, highlighting the influence of inter-annual variability (which is discussed in Sect. 4) and the magnitude of the trends depends on the chosen time period (i.e. small values at the beginning and/or high values at the end lead to high trends). Hence, the derived trends for these shorter periods 
should not immediately be assumed to indicate a significant recent acceleration in the rate of rise, which is discussed later (Sect. 6).

Tab. 1. Linear RMSL trends ( \pm standard errors) for all sites and common time periods (trends are calculated when $>75 \%$ of data are available); bold values indicate the highest trends derived for the five timer periods.

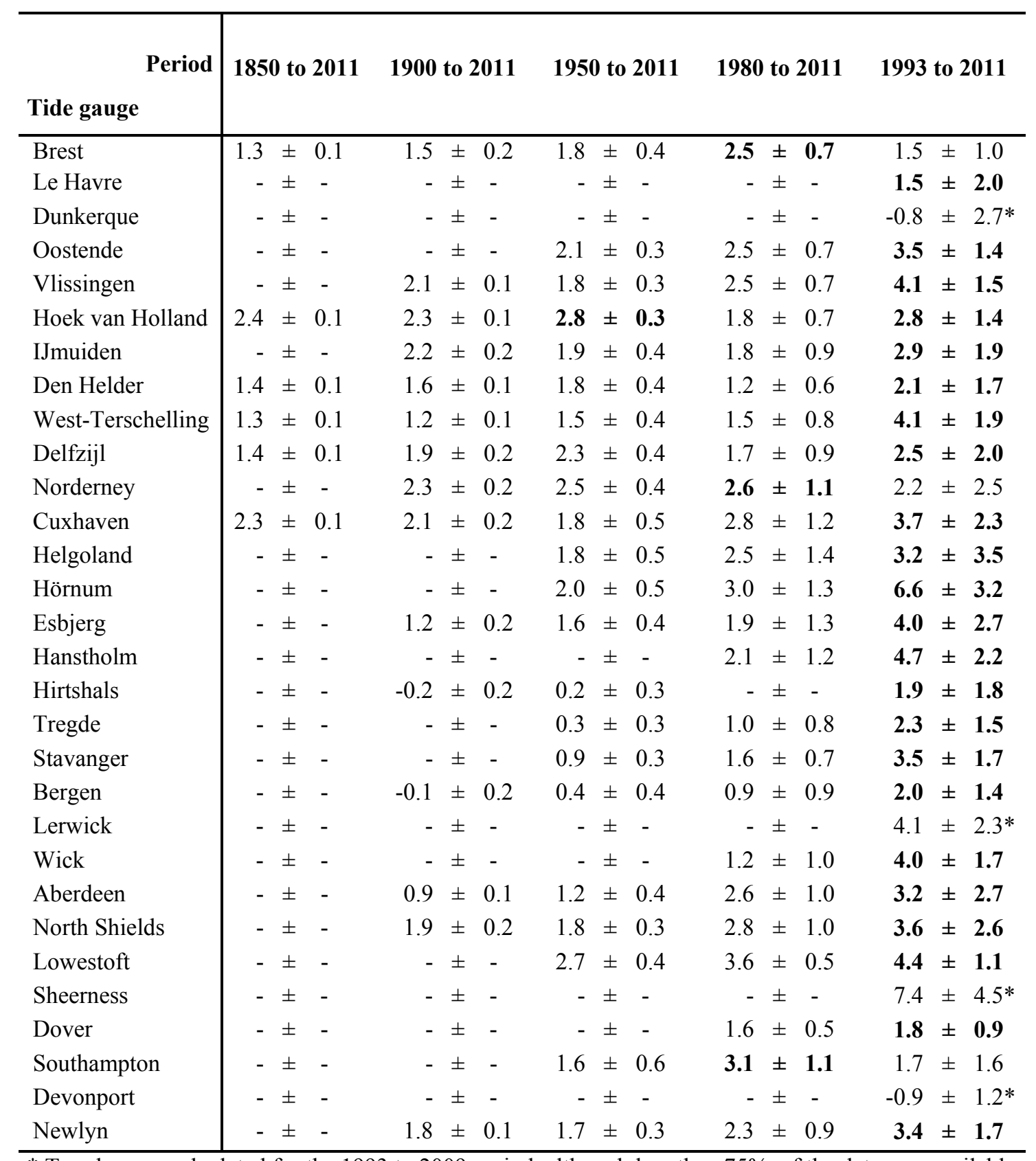

* Trends were calculated for the 1993 to 2009 period, although less than $75 \%$ of the data was available for this period (but at least $52 \%$ ) 


\section{Inter-annual and decadal sea level variability}

The second study objective is to examine the inter-annual and decadal variations in RMSL across the 30 sites. Woodworth et al. (2009a) pointed out that this is an important topic as the variability affects both the value of the sea level trend and its SE. In this paper, we use interannual to refer to variations in MSL from year to year and decadal to refer to variations of 10 years or greater.

\subsection{Inter-annual variability}

We start by examining the coherence of the year-to-year MSL variability across the region and its influence on the value of the estimated sea level trend and its associated uncertainty. In Tab. 1 the SE's associated with the estimated trends are not only larger for the shorter time periods, but the magnitude also varies across the 30 study sites. For each of the five time periods, the SE's tend to be larger for the Dutch, German and parts of the Danish coastlines. To assess this further, we calculate the standard deviation $(\sigma)$ of the annual MSL time series at each site after de-trending the record over the complete data length at that respective site. This is shown in Fig. 3 by the colour dots.

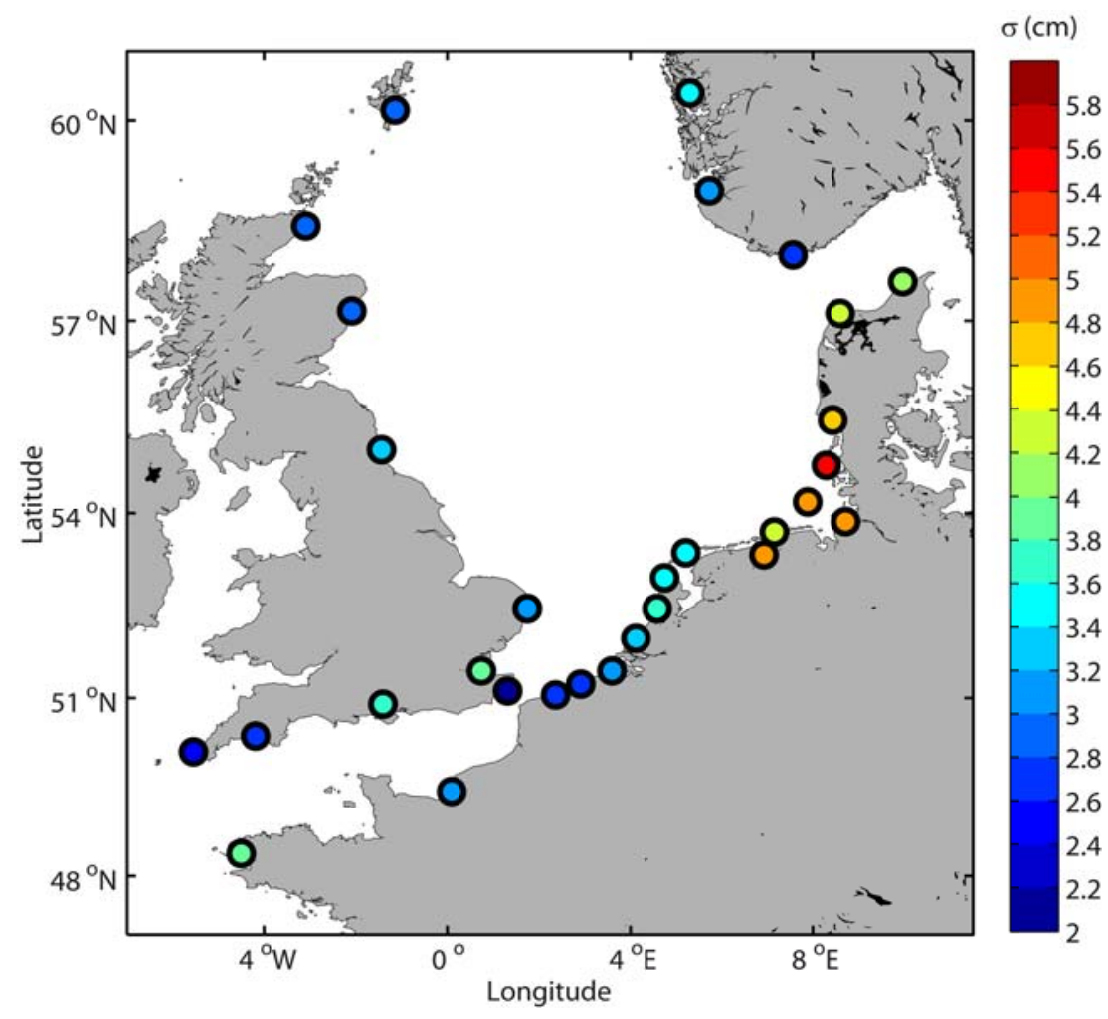

Fig. 3. Standard deviation of the de-trended annual RMSL time series from the 30 study sites (entire record lengths). 
As expected from the results presented in Tab. 1, the year-to-year variability in annual mean values is largest along the southern Danish, the German and the north-eastern Dutch coastlines. The standard deviation is highest for the tide gauge of Hörnum in the southeast of Sylt Island $(\sigma=5.4 \mathrm{~cm})$. The south-eastern North Sea coastline is exposed to persistent westerly winds (i.e. the prevailing wind direction in the North Sea). This leads to the large inter-annual variability in this area, as Dangendorf et al. (2013) recently showed for the long tide gauge record of Cuxhaven as an example.

As the year-to-year variability in MSL (along with the serial correlation) influences the SE's associated with the estimated trends, longer records are required from areas experiencing large inter-annual variability to achieve the same level of accuracy compared to areas where the variability is smaller. When analysing datasets from different parts of the world, Douglas (1991), Tsimplis and Spencer (1997), Woodworth et al. (1992), Woodworth et al. (1999) and Haigh et al. (2009) demonstrated that 30 and 50 years of records are required to obtain SE's in the order of 0.5 and $0.3 \mathrm{~mm} / \mathrm{yr}$, respectively (the influence of serial correlation was omitted in these earlier studies). When serial correlation is ignored, this corresponds well with the SE's obtained for most of the French, Belgium, Danish, Norwegian and UK records (not shown). However, for the Dutch and German coastlines, records need to be longer to obtain the same accuracy in the trend estimates. Fig. 4 demonstrates this point and shows SE's calculated for different length subsets (i.e. varying data lengths) of three tide gauge records.

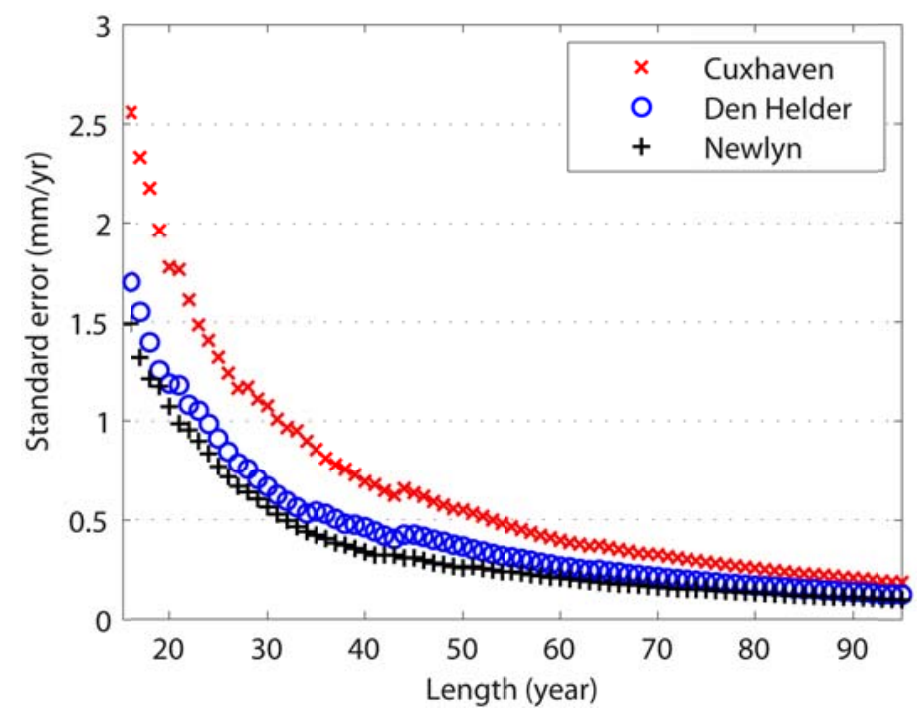

Fig. 4. Standard errors associated with RMSL trends for different data lengths for three sites (Cuxhaven, Den Helder and Newlyn).

At this stage it was assumed that the time series were not serially correlated in order to outline how the inter-annual variability (which usually dominates over the effect of serial correlation) 
affects the SE's. The sites were chosen as they provide records longer than 90 years without gaps and cover a wide range of the inter-annual variability in the investigation area, with standard deviations of $2.6 \mathrm{~cm}$ (Newlyn, UK), $3.5 \mathrm{~cm}$ (Den Helder, Netherlands) and $4.9 \mathrm{~cm}$ (Cuxhaven, Germany). To obtain standard errors of $0.5 \mathrm{~mm} / \mathrm{yr}(0.3 \mathrm{~mm} / \mathrm{yr})$ record lengths of about 55 (75), 40 (55) and 30 (45) years are required for Cuxhaven, Den Helder and Newlyn, respectively. A bump appears for a record length of 42 years (i.e. data from 1967 to 2009 are considered). This results from the particular high values, which occurred in 1967 first of all at the Cuxhaven and Den Helder tide gauges (see Fig. 2) due to persistent on-shore winds (Dangendorf et al., 2013).

In the following we examine the extent to which the inter-annual variability is coherent across the North Sea region. For each site in turn, correlation coefficients were calculated between the annual RMSL time series at that site and each of the other 29 sites. The results are shown in Fig. 5.

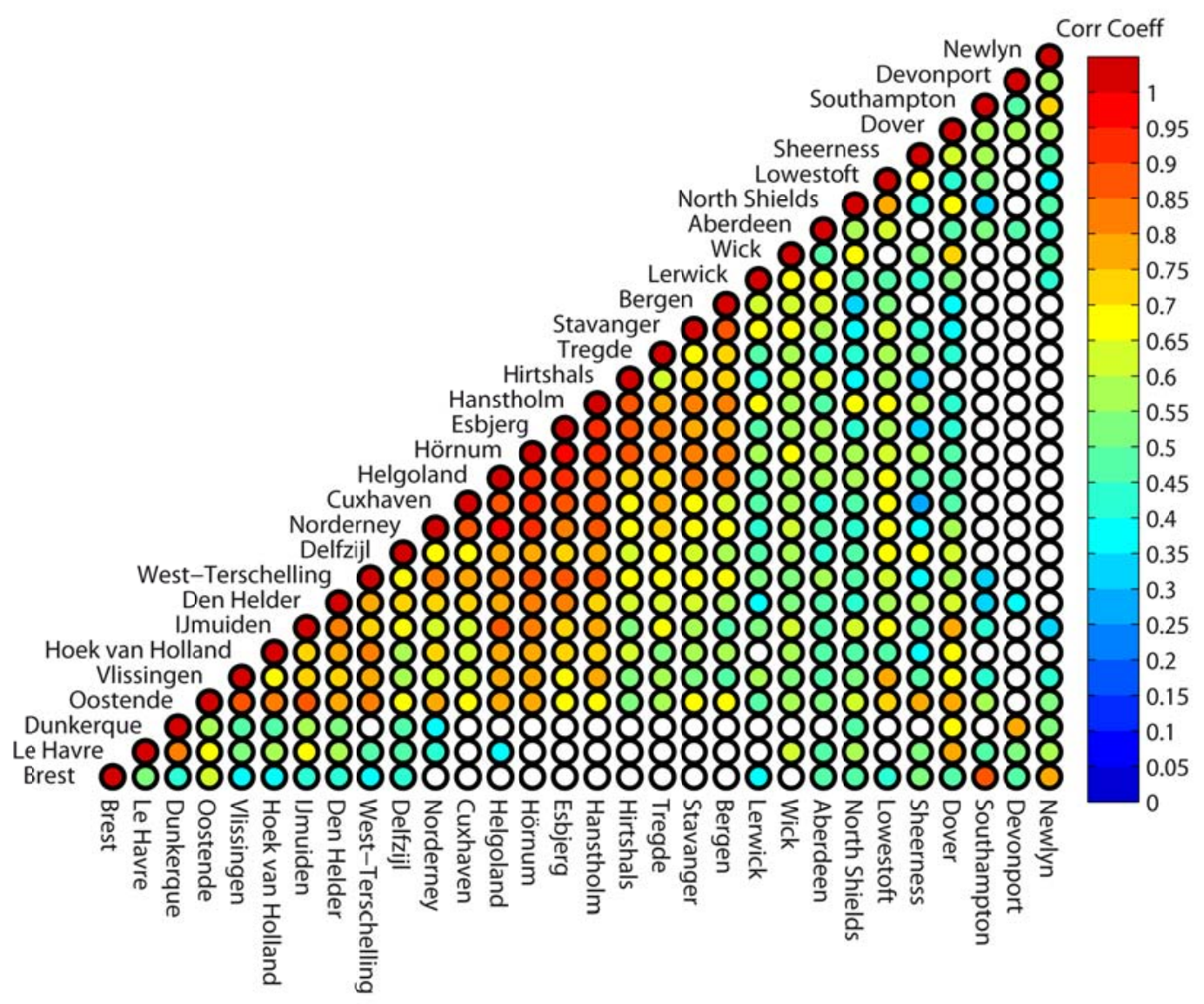

Fig. 5. Correlation coefficients matrix for individual stations. Circles are left blank when the correlation is not statistically significant on $95 \%$ level. 
Blank circles show when the correlation is not significant at the $95 \%$ confidence level between pairs of sites. All sites along the Belgian, Dutch, German, Danish and Norwegian coastlines (i.e. from Oostende to Bergen) are highly correlated with one another. Correlation is slightly weaker, but still statistically significant, for the UK east coast sites (i.e. Lerwick to Dover). The sites in the English Channel (i.e. Southampton, Devonport, Newlyn, Brest, Le Havre) are significantly correlated with one another but are not significantly correlated with most North Sea sites.

Shennan and Woodworth (1992), and many subsequent authors (e.g. Woodworth et al., 1999, 2009a; Haigh et al., 2009; Albrecht et al., 2011; Hamlington et al., 2011; Ray and Douglas, 2011; Wahl et al., 2011;), computed sea level indices representing the coherent part of the inter-annual MSL variability for specific regions. Indices were calculated by either averaging de-trended annual MSL time series across a number of records or using Empirical Orthogonal Function (EOF) techniques. As it is apparent that the inter-annual MSL variability in the English Channel seems to differ in character from the variability in the Inner North Sea (see Fig. 5), we construct three different indices. A North Sea index is derived using data from all sites and separate indices are constructed for the Inner North Sea (tide gauges from Oostende to Sheerness, i.e. no. 4 to 26 in Fig. 1) and for the English Channel (tide gauges Dover, Southampton, Devonport, Newlyn, Brest, Le Havre and Dunkerque).

The three indices, derived by calculating an arithmetic mean for each year across all the sites and subsets of those, are shown in Fig. 6a for the period from 1880 to 2011. All records were de-trended for the baseline period 1935 to 2011, a period covered by the majority of sites, in order to remove low-frequency contributions from geological and climate variability (Woodworth et al., 1999). The standard deviation about the mean is also shown for each year (grey bars in Fig. 6a). Each index covers the same period as the longest individual record considered for the construction. Hence, the English Channel and North Sea indices both start in 1807 (Brest is the longest record) and the Inner North Sea index in 1827 (Delfzijl is the longest record). Fig. $6 \mathrm{~b}$ shows the number of records used to construct the different indices for each year. The English Channel index is identical to the Brest record before 1916 when Newlyn starts and then consists of up to seven records for the later years. The Inner North Sea index starts with Delfzijl, before three to four records provide data from the mid to late $19^{\text {th }}$ century and then the number increases to up to 23 records in the second half of the $20^{\text {th }}$ century. One might argue that a few or even just one tide gauge record cannot adequately represent the inter-annual variability in a wider region. However, the strong correlation 
between the individual records shown in Fig. 5 confirms that large parts of the variability are accurately captured by a few or only one long record (see also Holgate, 2007).

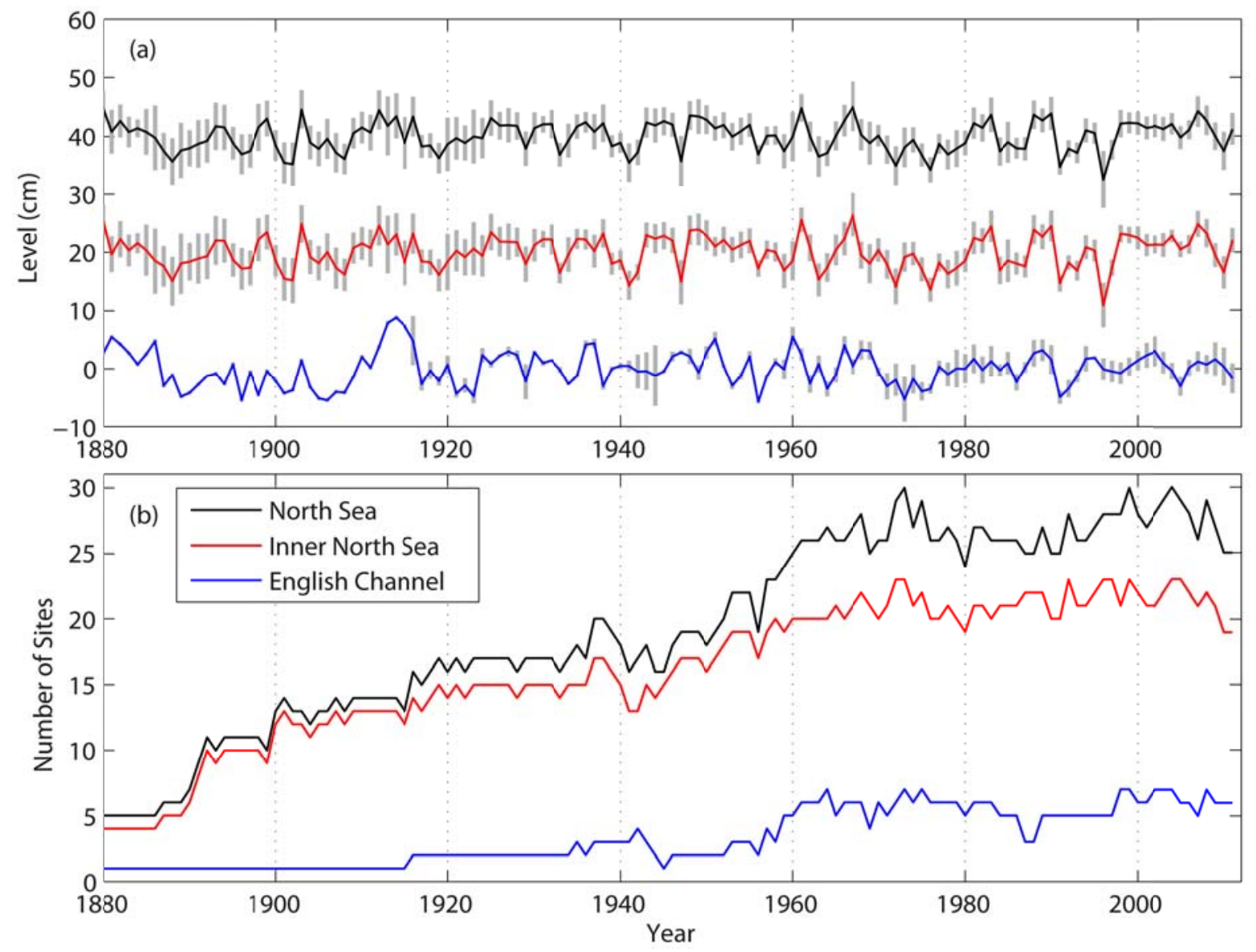

Fig. 6. (a) Indices derived by calculating an arithmetic mean across de-trended (for the baseline period from 1935 to 2011) North Sea, Inner North Sea and English Channel records with standard deviations about the mean (grey bars); (b) number of records available for constructing the indices.

The North Sea index, shown in Fig. 6a, is virtually the same as the Inner North Sea index, which is expected, given that the majority of the study sites are located in the Inner North Sea. However, the variability in the English Channel index is somewhat distinct from that present in the Inner North Sea index. The correlation between the Inner North Sea and English Channel indices is weak but significant (on the 95\% confidence level), with a correlation coefficient of $\mathrm{R}=0.37$ for the 1880 to 2011 period shown in Fig. 6a. Before 1960, the two indices are distinctly different. This could be due to the fact that the English Channel index is constructed from only one to three records for most years in this period (see Fig. 6b). After 1960, the variability in the two indices appears to be more consistent, with a slightly higher correlation coefficient of $\mathrm{R}=0.42$ for the period from 1960 to 2011 . The year 1996 provides a 
clear exception, as there are very small values in the Inner North Sea index, but not in the English Channel Index. Woodworth et al. (2009b) argued that this sharp drop was driven by the high negative state of the North Atlantic Oscillation (NAO) at that time, with a stronger influence on the Inner North Sea compared to the English Channel.

The indices presented in Fig.6a were compared to those derived using more sophisticated EOF analysis technique as described for example by Albrecht et al. (2011). For overlapping time periods, the difference between the indices was found to be small, consistent with the results presented by Woodworth et al. (1999) and Haigh et al. (2009), who analysed UK and English Channel sea level records, respectively.

The standard deviation is $4.6 \mathrm{~cm}$ for the North Sea and English Channel indices, and is $4.2 \mathrm{~cm}$ for the Inner North Sea index. Woodworth et al. (2009a) showed that sea level indices can be used as 'master stations' to remove the coherent part of the variability from the individual records, prior to fitting trends. Haigh et al. (2009) used that approach and showed that trends can be determined to a higher level of accuracy with the master station approach, especially when short records are investigated. The effect of using the North Sea index as the 'master station' has been examined and the results (not shown) indicate that the trends (relative to the individual record lengths) do not change significantly compared to those derived from the original data sets for the majority of sites. However, the SE's associated with the trends (serial correlation ignored) are on average reduced by $24 \%$ with the maximum reduction of $55 \%$ at the tide gauge at West-Terschelling, where the record is well correlated with many of the other sites and hence with the North Sea index used as master station.

\subsection{Decadal variability}

In the following, we investigate longer-term changes in the MSL variability and attempt to relate the fluctuations to large-scale climate drivers. Several studies have attempted to relate the variability of European sea level to the large-scale air pressure changes, e.g. represented by the NAO (e.g. Wakelin et al., 2003; Woolf et al., 2003; Tsimplis et al., 2005; Tsimplis et al., 2006; Kolker and Hameed, 2007; Haigh et al., 2010; Dangendorf et al., 2012; Albrecht and Weisse, 2012). Following Woodworth et al. (2009a), we focus on the relationship between the North Sea sea level index and mean sea level pressure (MSLP) over the investigation area. Gridded monthly MSLP records (grid spacing $2^{\circ} \times 2^{\circ}$ ) spanning the time period from 1871 to 2010 were downloaded from the National Oceanic and Atmospheric Administration's (NOAA) "Twentieth Century Reanalysis Project" (Compo et al., 2011) website (http://www.esrl.noaa.gov/psd/data/20thC_Rean/). An MSLP index was then 
constructed (in the same way the sea level indices were constructed; see Sect. 4.1) based on the annual MSLP time series from the grid points closest to the 30 tide gauge sites.

The sea level index is shown in Fig. 7a for the period from 1880 to 2010 with the negative of the MSLP index. For presenting purposes the latter was scaled to have the same standard deviation as the sea level index. Both time series were smoothed with a 10-yr running mean. The two time series show reasonable agreement during certain periods. The high sea level variability peaks in the 1900's and 1910's are reflected in the MSLP fluctuations. The correlation coefficient for the entire period is $\mathrm{R}=0.40$ for the annual time series (explained variance is $15 \%$ ) and $\mathrm{R}=0.57$ for the low pass filtered time series (explained variance is $33 \%$ ). Fig. $7 \mathrm{~b}$ shows 20 -yr running correlation coefficients between the 10-yr filtered sea level and MSLP indices and Fig. 7c shows the same results but on a scatter plot.
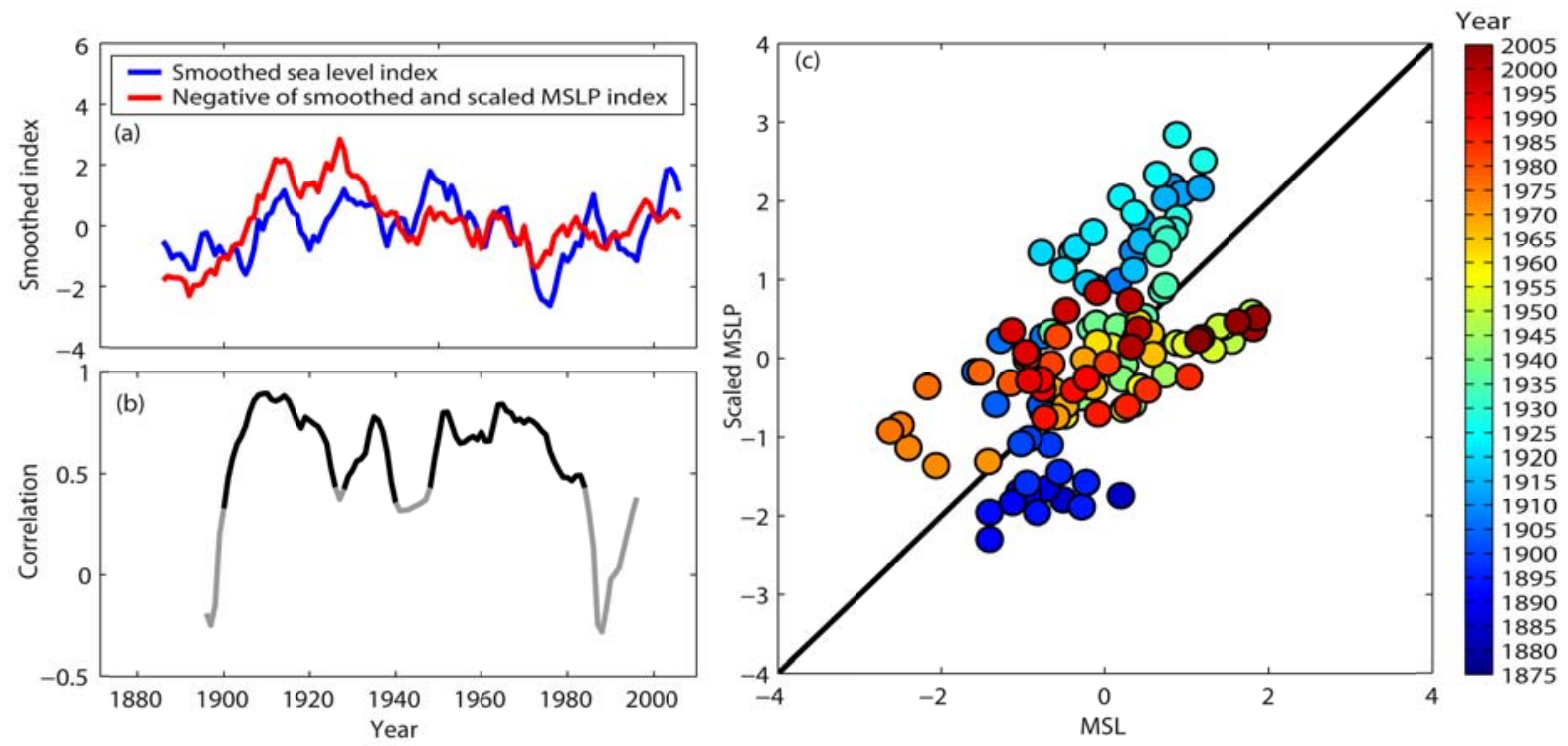

Fig. 7. (a) Comparison between the North Sea sea level index and the negative of a scaled MSLP index (both time series low pass filtered with a 10-yr running mean); (b) running 20-yr correlation between the time series shown in (a), with significant correlation shown in black; (c) scatter plot of the time series shown in (a).

The 20-yr running correlation between sea level and MSLP varied significantly throughout the last 130 years, with periods where the correlation was close to one (e.g. beginning of the $20^{\text {th }}$ century) and others with zero or even negative correlation (end of the $19^{\text {th }}$ century and recent decade(s)). Several inflexion points occur in both time series and often coincide (for example at the beginning of the $20^{\text {th }}$ century). However, Fig. 7 also demonstrates that parts of the observed sea level variability in the North Sea region are not coincident with MSLP 
variations and hence must have been driven by other forcing factors, such as oceanographic and meteorological influences, river run off or precipitation (Woodworth et al., 2009a). The influence of meteorological forcing on sea level variability at the tide gauge Cuxhaven has recently been investigated by Dangendorf et al. (2013). They showed that zonal wind stress explains more than $50 \%$ of the observed sea level variability across all seasons, and up to $87 \%$ in the winter season.

To investigate at which sites MSLP variations have on average most influenced sea level variability in the past, correlation coefficients were calculated between the de-trended RMSL records at individual sites and the related de-trended MSLP time series from the nearest grid points. The coefficients are shown in Fig. 8.

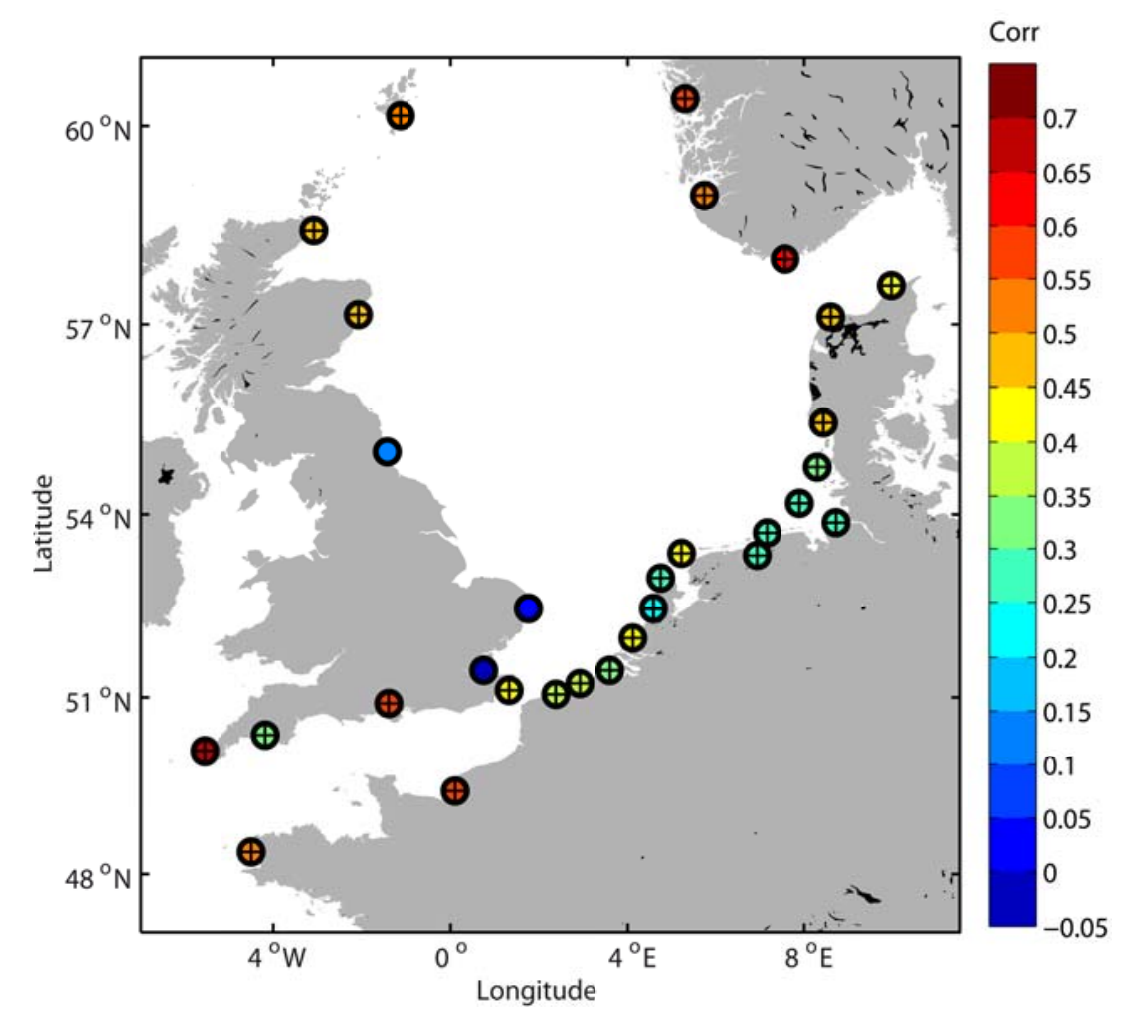

Fig. 8. Correlation between sea level time series from individual records and the negative of the MSLP time series from the nearest grid points; significant correlations (95\% confidence level) are marked with a '+'.

With the exceptions of North Shields, Lowestoft and Sheerness, all of the correlation coefficients are significant at the 95\% confidence level. Correlations coefficients are higher for the sites in the English Channel, along northern Denmark, Norway and the north-eastern UK (Aberdeen and north) coastline, indicating that sea level variability is strongly linked to MSLP variations in these areas. Correlation is weaker along the south-eastern UK (North Shields to Sheernes), Belgian, Dutch, German and parts of the Danish coastlines, where the 
inter-annual sea level variability was also found to be large (see Fig. 3) and dominated by variations in wind stress. Hence, correcting MSL records for the 'inverse barometer' (IB) significantly reduces the variability at some tide gauges and thereby improves the accuracy of trend estimations, whereas other forcing factors (such as local winds, river runoff, precipitation) need to be taken into account at other sites to achieve a significant reduction in the variability. The latter is an important topic to allow for robust trend estimations and for being able to reliably detect non-linear changes in the rates of sea level rise (i.e. acceleration) as early as possible after they take place.

\section{Vertical land movement and absolute sea level changes}

An important issue in MSL studies is separating AMSL changes from RMSL changes, and this is the third objective of the study. In the following, information from various sources are considered and rates of vertical land movement (VLM) at the study sites are presented. Afterwards, these VLM rates are taken into account to calculate geocentric sea level trends for the North Sea region.

\subsection{Rates of vertical land movement}

The vertical land movement contributions to relative sea level changes can be as large as the climate contribution itself (Woodworth, 2006) and different approaches have been used in the past to remove these influences to estimate geocentric rates of change. One way of correcting the observed RMSL records is using predictions of RMSL changes from geological information (e.g. Shennan and Woodworth, 1992; Shennan and Horton, 2002; Gehrels and Woodworth, 2012) or models capable of simulating glacial isostatic adjustment, the rebound effect resulting from the last de-glaciation (e.g. Peltier, 2004; Bradley et al., 2009; Hansen et al., 2011; Shennan et al., 2012). GIA is the only vertical land movement process that can be modelled on a global basis and for which we can get VLM predictions with uncertainties similar to those of RMSL rates from tide gauges. However, vertical motions due to other geological processes are not included.

For the present study, we use estimates of the influence of vertical land motions (i.e. predictions of RMSL changes) from GIA models as well as from geological surveys (see columns 2 and 4 in Tab. 2). The results from GIA modelling for the UK sites were taken from Shennan et al. (2012), as these are considered the current best estimates for this area. Their GIA model incorporates geological information. However, Shennan et al. (2012) do not 
provide results for areas outside the UK and therefore the values for the remaining sites are based on Peltier's ICE5Gv1.3 (VM2) model (Peltier, 2004) and were downloaded from the PSMSL website. Error estimates are not available for the GIA values. Predicted RMSL changes derived from geological data were taken from Shennann and Horton (2002) for the UK sites and from Shennan and Woodworth (1992) for the remaining sites. All of these values were extracted from the database with late Holocene sea level index points at the University of Durham (Tooley, 1982). Shennan and Horton (2002) do not provide error estimates, so we follow Woodworth et al. (2009a) and assume $0.2 \mathrm{~mm} / \mathrm{yr}$ for all stations.

As Woodworth (2006) pointed out, where possible, the correct scientific approach is to measure VLM directly at the tide-gauge. With the recent advances in geodetic techniques (Wöppelmann et al. 2007, 2009; Bradley et al., 2009; Schöne et al., 2009; Teferle et al., 2009; Bouin and Wöppelmann, 2010; Santamaría-Gómez et al., 2012), this is possible with increasing accuracy. Considerable efforts are being undertaken worldwide to upgrade tide gauge networks with collocated CGPS receivers. However, the number of CGPS stations is still small compared to the dense tide gauge network. Furthermore, geodetic connections between the CGPS stations and the nearest tide gauges are often missing, where the receivers are not located at the actual tide gauge sites. This raises the question whether the nearby measured vertical motions represent the exact motion at the tide gauge (Wöppelmann and Marcos, 2012). In addition, many of the CGPS records are still short and contain substantial noise. Hence, calculating VLM rates (which are required to correct long relative sea level records) can often not be determined to the required degree of accuracy (i.e. the uncertainties in the vertical rates should be much smaller than the sought-after climate related AMSL changes) (Wöppelmann et al., 2009).

For the present study, estimates derived from the latest CGPS solution (ULR5) (Santamaría-Gómez et al., 2012) were provided by the SONEL group (www.sonel.org) and are available for 13 of the 30 study sites. These are displayed with formal errors (taking into account the temporal correlation) in Tab. 2 along with additional information on the distances between the CGPS antenna and the tide gauges. The lengths of the CGPS records are also included, as these determine the level of accuracy of the vertical rates.

Since 1992, satellites provide a quasi-global coverage of MSL measurements and have also been used to derive estimates of the rates of VLM at specific sites. Cazenave et al. (1999) and different authors since then (e.g. Nerem and Mitchum, 2002; Garcia et al., 2007; Ray et al., 2010) compared altimetry data with those from collocated tide gauges for overlapping time periods. Relying on the assumption that the differences between the two data sources 
mainly result from vertical land motion, the slope of the differences between the two data sets represents an estimate of the rate of VLM at the specific site. A more sophisticated approach, considering altimetry data as well as data sets from adjacent tide gauges, was introduced by Kuo et al. (2004). This approach was recently adopted by Wöppelmann and Marcos (2012) to analyse rates of coastal sea level rise in southern Europe.

We also use the information from satellite altimetry to calculate VLM rates at the study sites. The altimetry dataset was downloaded from the Archiving, Validation, and Interpretation of Satellite Oceanographic (AVISO) web data server. It consists of monthly MSL anomalies for the period from 1993 to 2011 on a global grid (grid spacing $1 / 4^{\circ} \times 1 / 4^{\circ}$ ). Firstly, we calculated annual MSL time series from the altimetry grid points closest to the tide gauge sites. Secondly, we determined the correlation coefficients between the tide gauge and altimetry time series. Thirdly, for those sites where the correlation was significant on the $95 \%$ confidence level, we subtracted the annual tide gauge MSL time series from the annual altimetry MSL time series. In order to account for the IB correction present in the altimetry data, the same correction was applied to the tide gauge time series by using the MSLP data set described in section 4.2. Finally, we calculated the linear trends and standard errors of the residuals. The results are assumed to represent the VLM rates and are shown in column 5 of Tab. 2.

As outlined above, there are generally two sources of information available when assessing AMSL, namely predictions of RMSL changes (from geological information or GIA models) and measured VLM rates (from CGPS or from comparing altimetry and tide gauge data). Several authors highlighted (mostly in the recent past, as there was some confusion due to inconsistent terminology between disciplines) that there is a difference between these two (e.g. Peltier, 2001; Tamisiea, 2011; Tamisiea and Mitrovica, 2011; King et al., 2012; Shennan et al., 2012). The difference results from the GIA effect on the potential sea surface height (or geoid of the ocean) due to changes in the bathymetry and expansion of the ocean basins (see e.g. Fig. 2 in Tamisiea and Mitrovica, 2011). Altimetry data sets are routinely corrected for this GIA influence when being compared or combined with GIA corrected tide gauge records (e.g. Church and White, 2011). The GIA contribution to changes in the sea surface is already considered in the RMSL predictions but needs to be accounted for when using VLM rates to transfer RMSL to AMSL. The global average difference between VLM and the negative of RMSL predictions is generally cited as $-0.3 \mathrm{~mm} / \mathrm{yr}$ (Peltier, 2001); spatially the difference varies significantly, between +2.5 and $-1.5 \mathrm{~mm} / \mathrm{yr}$ (Shennan et al., 2012). The last column of Tab. 2 shows the differences $\left(\Delta_{\text {Geoid }}\right)$ for the 30 study sites. These values were obtained by 
subtracting RMSL predictions from VLM predictions, both derived with Peltier's ICE5Gv1.3 (VM2) model and downloaded from the PSMSL website. The differences between VLM and negative of predicted RMSL vary between $-0.04 \mathrm{~mm} / \mathrm{yr}$ and $-0.39 \mathrm{~mm} / \mathrm{yr}$ with an average of $0.23 \mathrm{~mm} / \mathrm{yr}$. In order to compare the rates listed in columns 2 to 5 of Tab. 2, the VLM rates need to be transferred into RMSL predictions by subtracting the $\Delta_{\text {Geoid }}$ values, or the other way round, the $\Delta_{\text {Geoid }}$ values need to be added to the negatives of the RMSL predictions to turn these into VLM rates.

The resulting VLM rates (not shown) derived from GIA, CGPS and geological data vary in the magnitude but at least the signs, indicating land uplift or land subsidence, are in the same directions in most cases. The exceptions are Helgoland, Esbjerg, Lerwick, North Shields and Sheerness. The VLM rates obtained from comparing altimetry and tide gauge data are consistent with the rates derived from the other methods at some sites, but disagree in the sign (e.g. Hoek van Holland, Stavanger) or magnitude (e.g. Hörnum) at others. These results suggest that comparing relatively short time series (with a large inter-annual variability) derived from tide gauges and altimetry measurements is not yet expedient for the North Sea. Furthermore, it is well known, that altimetry products have to be used carefully in coastal zones (e.g. Madsen et al., 2007), but it is hoped that on-going efforts (see e.g. Vignudelli et al., 2011 and www.coastalt.eu) will contribute to overcome these issues. Wöppelmann and Marcos (2012) succeeded in applying a more sophisticated approach, based on altimetry and tide gauge data from adjacent sites, to correct RMSL records from tide gauges along the coastline of southern Europe. This approach relies on a few assumptions and its applicability to the North Sea coastline needs to be tested. The data set considered for the present study could be used for this purpose. Applying the 'advanced' approach could potentially improve the estimates of AMSL changes presented in this paper. Overall the values in Tab. 2 are consistent with the known pattern of land uplift in the north of Denmark, Norway and the northern parts of the UK and subsidence in the remaining areas.

Tab. 2. Predictions of RMSL changes $\left(\mathrm{RMSL}_{\mathrm{GIA}}\right.$ and $\left.\mathrm{RMSL} \mathrm{L}_{\text {Geology }}\right)$ and VLM rates (VLM ${ }_{\mathrm{CGPS}}$ and $\mathrm{VLM}_{\mathrm{AL}-\mathrm{TG}}$ ) at the 30 tide gauge sites derived with different methods (negative values denote subsidence). $\Delta_{\text {Geoid }}$ is the gravity contribution of GIA to SLR (or the effect of GIA on the equipotential surface (or the geoid) of the ocean). If not stated otherwise, the unit is $\mathrm{mm} / \mathrm{yr}$. 


\begin{tabular}{|c|c|c|c|c|c|c|c|c|c|c|c|c|c|}
\hline \multirow[b]{2}{*}{ Tide gauge } & \multicolumn{3}{|c|}{ - RMSL $_{\text {GIA }}$} & \multicolumn{3}{|c|}{ VLM $_{\text {CGPS }}$} & \multicolumn{3}{|c|}{ - RMSL $\mathbf{G e o l o g y}$} & \multicolumn{3}{|c|}{$\mathbf{V L M}_{\mathrm{AL}-\mathrm{TG}}$} & \multirow{2}{*}{$\begin{array}{c}\Delta_{\text {Geoid }} \\
\text { Rate }\end{array}$} \\
\hline & Rate & & Error & Rate & Error & $\begin{array}{l}\text { Dist. | Length } \\
(\mathrm{m}) \quad(\mathrm{yr})\end{array}$ & Rate & & Error & Rate & & Error & \\
\hline Brest & -0.22 & \pm & - & -1.14 & \pm 0.12 & $350 \mid 12.16$ & - & \pm & - & - & \pm & - & -0.38 \\
\hline Le Havre & 0.18 & \pm & - & - & $\pm \quad-$ & - & - & \pm & - & - & \pm & - & -0.32 \\
\hline Dunkerque & 0.11 & \pm & - & - & \pm & - & - & \pm & - & - & \pm & - & -0.28 \\
\hline Oostende & 0.09 & \pm & - & - & \pm & - & - & \pm & - & -0.90 & \pm & 1.34 & -0.27 \\
\hline Vlissingen & 0.06 & \pm & - & - & \pm & - & - & \pm & - & -0.25 & \pm & 1.35 & -0.27 \\
\hline Hoek van Holland & -0.04 & \pm & - & - & \pm & - & -0.50 & \pm & 0.05 & 2.14 & \pm & 1.34 & -0.26 \\
\hline IJmuiden & -0.16 & \pm & - & - & \pm & - & -0.50 & \pm & 0.05 & -0.54 & \pm & 1.39 & -0.25 \\
\hline Den Helder & -0.30 & \pm & - & - & $\pm \quad-$ & - & -0.50 & \pm & 0.05 & -0.02 & \pm & 1.19 & -0.24 \\
\hline West-Terschelling & -0.43 & \pm & - & -0.15 & \pm 0.11 & $10 \mid 14.16$ & -0.50 & \pm & 0.05 & -0.98 & \pm & 1.83 & -0.23 \\
\hline Delfzij1 & -0.37 & \pm & - & - & $\pm \quad-$ & - & -0.60 & \pm & 0.04 & 0.61 & \pm & 1.10 & -0.21 \\
\hline Norderney & -0.47 & \pm & - & - & \pm & - & - & \pm & - & 1.25 & \pm & 1.44 & -0.21 \\
\hline Cuxhaven & -0.36 & \pm & - & - & $\pm \quad-$ & - & -0.68 & \pm & 0.10 & -0.32 & \pm & 1.34 & -0.18 \\
\hline Helgoland & -0.51 & \pm & - & 0.49 & \pm 0.19 & $150 \mid 11.13$ & - & \pm & - & 2.01 & \pm & 1.86 & -0.21 \\
\hline Hörnum & -0.57 & \pm & - & - & $\pm \quad-$ & - & - & \pm & - & -2.90 & \pm & 1.56 & -0.17 \\
\hline Esbjerg & -0.54 & \pm & - & -1.17 & \pm 0.35 & $5 \mid 6.13$ & 1.44 & \pm & 0.10 & -0.90 & \pm & 1.28 & -0.16 \\
\hline Hanstholm & 0.41 & \pm & - & - & $\pm \quad-$ & - & - & \pm & - & -1.52 & \pm & 0.77 & -0.09 \\
\hline Hirtshals & 1.34 & \pm & - & 2.80 & \pm 0.21 & $500 \mid 6.13$ & 1.44 & \pm & 0.10 & 1.75 & \pm & 0.90 & -0.04 \\
\hline Tregde & 0.99 & \pm & - & 1.54 & \pm 0.19 & $5 \mid 8.68$ & - & \pm & - & 0.75 & \pm & 0.83 & -0.08 \\
\hline Stavanger & 1.14 & \pm & - & 1.84 & \pm 0.17 & $10.000 \mid 10.15$ & 1.31 & \pm & 0.05 & -0.94 & \pm & 0.57 & -0.08 \\
\hline Bergen & 1.37 & \pm & - & - & $\pm \quad-$ & - & 1.31 & \pm & 0.05 & 0.65 & \pm & 0.67 & -0.07 \\
\hline Lerwick & -1.00 & \pm & - & 0.44 & \pm 0.23 & $2 \mid 5.27$ & - & \pm & - & -1.17 & \pm & 0.55 & -0.23 \\
\hline Wick & 0.50 & \pm & - & - & & - & 0.40 & \pm & 0.20 & 0.14 & \pm & 1.16 & -0.26 \\
\hline Aberdeen & 0.60 & \pm & - & 0.87 & \pm 0.11 & $2 \mid 12.28$ & 0.70 & \pm & 0.20 & -1.39 & \pm & 0.99 & -0.26 \\
\hline North Shields & 0.20 & \pm & - & 0.67 & \pm 0.15 & $2 \mid 11.4$ & -0.20 & \pm & 0.20 & -1.74 & \pm & 2.54 & -0.09 \\
\hline Lowestoft & -0.50 & \pm & - & -0.62 & \pm 0.15 & $2 \mid 11.82$ & -0.60 & \pm & 0.20 & -1.96 & \pm & 0.91 & -0.28 \\
\hline Sheerness & -0.30 & \pm & - & 1.03 & \pm 0.25 & $2 \mid 13.75$ & -1.42 & \pm & 0.20 & -5.16 & \pm & 2.54 & -0.30 \\
\hline Dover & -0.30 & \pm & - & - & $\pm \quad-$ & - & -0.70 & \pm & 0.20 & - & \pm & - & -0.29 \\
\hline Southampton & -0.30 & \pm & - & - & $\pm \quad-$ & - & -0.60 & \pm & 0.20 & - & \pm & - & -0.33 \\
\hline Devonport & -0.50 & \pm & - & - & $\pm \quad-$ & - & -1.20 & \pm & 0.20 & - & \pm & - & -0.37 \\
\hline Newlyn & -0.70 & \pm & - & -0.03 & \pm 0.14 & $5 \mid 12.24$ & -1.10 & \pm & 0.20 & - & \pm & - & -0.39 \\
\hline
\end{tabular}

\subsection{Geocentric Mean Sea Level trends in the North Sea}

We now use the values from Tab. 2 to estimate AMSL trends. Therefore we remove the influence of VLM and the GIA contribution to changes in the ocean surface from the observed RMSL time series at each study site by using the following equations (1) and (2).

$$
A M S L=R M S L_{O b s}-R M S L_{\text {Pred }}
$$


where $R M S L_{O b s}$ is the observed RMSL and $R M S L_{\text {Pred }}$ is the predicted RMSL (i.e. the influence of vertical land motion), derived either from GIA modelling (RMSL $\mathrm{GIA}$ ) or from geological information $\left(\mathrm{RMSL}_{\mathrm{Geology}}\right)$; and

$$
A M S L=R M S L_{O b s}-V L M-\Delta_{\text {Geoid }}
$$

where $R M S L_{O b s .}$ is the observed RMSL, VLM is the rate of vertical land movement, derived either from CGPS (VLM CGPS $_{\text {) }}$ or from comparing altimetry and tide gauge data $\left(\mathrm{VLM}_{\mathrm{AL}-\mathrm{TG}}\right)$, and $\Delta_{\text {Geoid }}$ is the GIA contribution to changes in the ocean surface. This gives us four different AMSL estimates, where the VLM rates were derived with different methods.

The RMSL trends for 1900 to 2011 for each of the sites providing more than $75 \%$ of data for this time period (see also Tab. 1) are shown in Fig. 9a. The spatial variability of the estimated trends is large. Figure $9 \mathrm{~b}$ shows the same results, but after correcting the individual RMSL trends, by following equations (1) and (2). The error bars represent the standard errors of the individual tide gauge trends, taken as dominating over the errors in the vertical rates (following Woodworth et al., 2009a). We recognize that the assumption is not valid in all cases, especially for the results from comparing altimetry and tide gauge data the uncertainties in the VLM rates are large (see Tab. 2) and clearly dominate over the standard errors of the tide gauge trends. However, for presenting purposes and as uncertainties were not available for the GIA estimates, errors were not propagated and displayed in Fig. 9b, but the information is included in Tab. 2.

The variability of the trends across the sites reduces significantly after relative trends are corrected for the influence of vertical land movement derived from GIA and geological data. Only seven of the 13 sites, for which CGPS estimates are available, provide enough data to determine robust trends for the 1900 to 2011 period. Looking at the corrected trends of these seven records indicates that CGPS fails at reducing the variability of the trends across the sites. The same is true for the trends corrected with the results from comparing altimetry and tide gauge data (AL-TG). The standard deviation across the observed RMSL trends is $0.81 \mathrm{~mm} / \mathrm{yr}$ and reduces to $0.51 \mathrm{~mm} / \mathrm{yr}$ and $0.54 \mathrm{~mm} / \mathrm{yr}$ after correcting with GIA and geological data, respectively. Correcting seven sites with CGPS and AL-TG increases the standard deviation to $0.96 \mathrm{~mm} / \mathrm{yr}$ and $1.43 \mathrm{~mm} / \mathrm{yr}$. The black line and the grey band in Fig. $9 \mathrm{~b}$ represent the results reported by Woodworth et al. (2009a). They determined that AMSL around the UK rose by $1.4 \pm 0.2 \mathrm{~mm} / \mathrm{yr}$ throughout the $20^{\text {th }}$ and early $21^{\text {st }}$ century (to 2006). 
The arrows on the right hand side of Fig. 9b show the long-term AMSL trends for 1900 to 2011 in the North Sea derived in the present study, by calculating weighted averages (over the SE's of the individual tide gauges) of the corrected trends across the sites. Linear trends of $1.53 \pm 0.16 \mathrm{~mm} / \mathrm{yr}, 1.44 \pm 0.16 \mathrm{~mm} / \mathrm{yr}, 1.74 \pm 0.16 \mathrm{~mm} / \mathrm{yr}$ and $1.77 \pm 0.16 \mathrm{~mm} / \mathrm{yr}$ are derived after correcting with GIA, geological data, CGPS and AL-TG, respectively. These are not significantly different (at the 95\% confidence level) from the trend estimated by Woodworth et al. (2009a), but, with the exception of the trend derived from geological data, are significantly higher than the $1.0 \pm 0.15 \mathrm{~mm} / \mathrm{yr}$ derived by Shennan and Woodworth (1992). Most of the tide gauge records in this earlier North Sea assessment ended in the late 1980s.

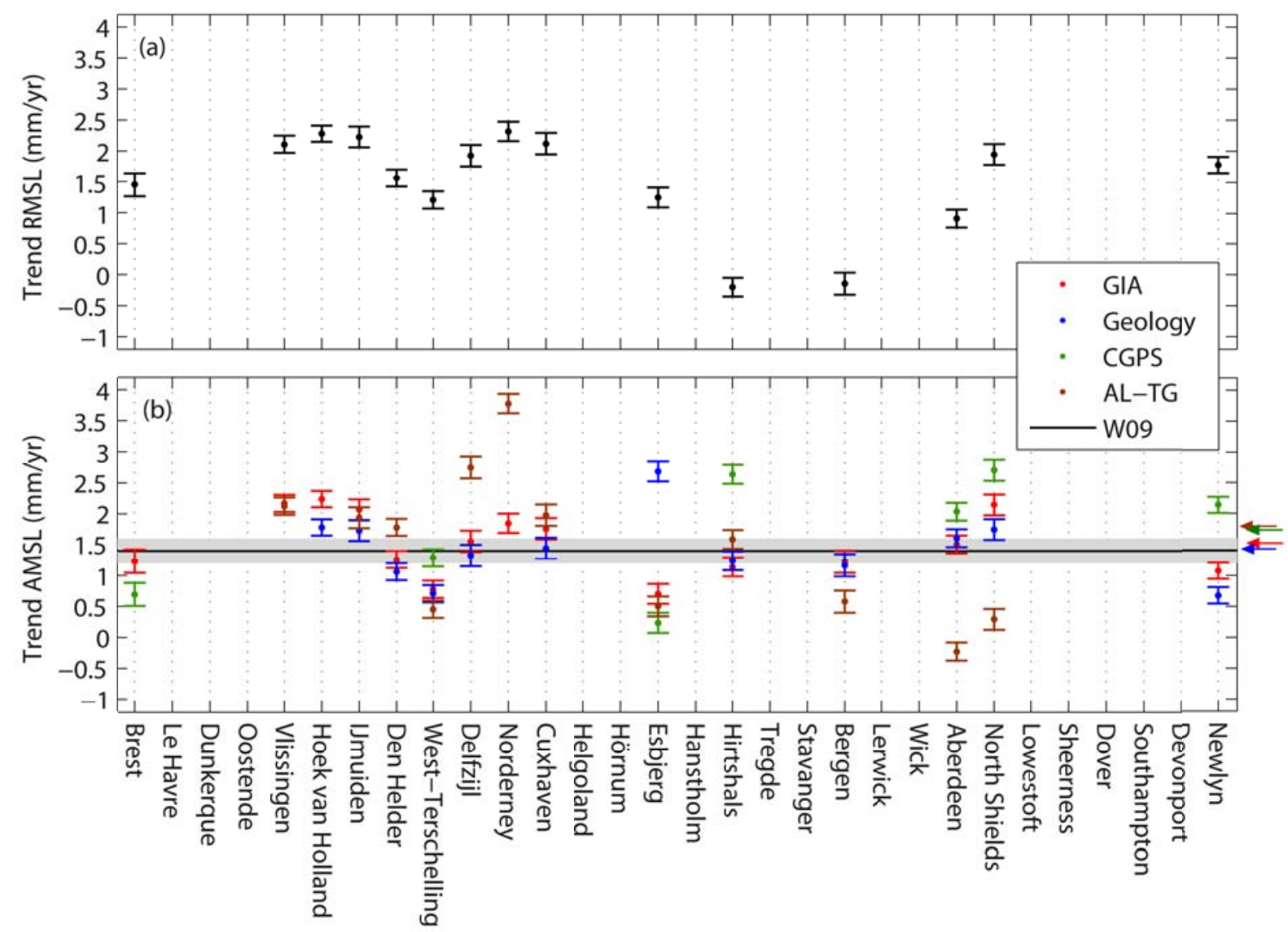

Fig. 9. (a) RMSL trends for the period 1900 to 2011 (see Table 1); (b) AMSL trends after correcting for rates of vertical land movement derived with different methods (i.e. GIA, Geological data, CGPS, AL-TG), the black line and grey band represent the results of Woodworth et al. (2009a; W09 in the legend) and the arrows on the right show the weighted averages for $20^{\text {th }}$ century sea level rise derived in the present study. 
If tide gauges from the Inner North Sea and the English Channel are considered separately, trends of $1.59 \pm 0.16 \mathrm{~mm} / \mathrm{yr}$ (GIA), $1.49 \pm 0.16 \mathrm{~mm} / \mathrm{yr}$ (geol. data), $1.81 \pm 0.16 \mathrm{~mm} / \mathrm{yr}$ (CGPS) and $1.77 \mathrm{~mm} / \mathrm{yr} \pm 0.16 \mathrm{~mm} / \mathrm{yr}$ (AL-TG) are found for the Inner North Sea and smaller trends of $1.18 \pm 0.16 \mathrm{~mm} / \mathrm{yr}$ (GIA), $0.82 \pm 0.16 \mathrm{~mm} / \mathrm{yr}$ (geol. data) and $1.59 \pm 0.16$ $\mathrm{mm} / \mathrm{yr}$ (CGPS) are estimated for the English Channel (a trend for the English Channel could not be calculated with the AL-TG approach). Church and White (2011) recently updated a global sea level reconstruction based on tide gauge and altimetry data and found an AMSL trend of $1.7 \pm 0.2 \mathrm{~mm} / \mathrm{yr}$ (weighted by the uncertainty estimates) for the 1900 to 2009 period. Thus, sea levels in the Inner North Sea have risen at almost the same rate as global sea levels (considering the GIA correction, which performed best in reducing the trend variability across the study sites). The trends for the English Channel are considerably smaller but also less robust, as they are calculated from only two stations (i.e. Brest and Newlyn), both of which are located at the westerly end of the Channel coastline. In addition, Gehrels (2006), Woodworth et al. (2009a) and Haigh et al. (2009) questioned the high rate of subsidence in earlier studies (i.e. Shennan and Horton, 2002) for the southwest coast of the UK, particularly at Newlyn. The estimate from CGPS at Newlyn is distinctly lower than the GIA and geological data estimate (Tab. 2, Fig. 9a).

\section{Non-linear sea level trends}

In recent years there has been increased attention on the issue of non-linear changes (i.e. 'accelerations' or 'decelerations') in the rate of global sea level rise on decadal and centennial time scales (e.g. Church et al., 2008; Jevrejeva et al., 2006, 2008; Woodworth et al., 2009b) and this is also analysed here for the North Sea. For the period 1993 to 2009, the estimated global MSL trend from altimetry records is $3.2 \pm 0.4 \mathrm{~mm} / \mathrm{yr}$, almost double that observed from 1900 to 2009 (Church and White, 2011). A number of authors have asked if the high rates of global sea level rise observed over the last few decades represent the start of an accelerated SLR due to anthropogenic climate change, or whether they represent decadal fluctuations. Different methods have been applied to examine non-linear changes in long sea level time series from individual sites and global or regional sea level reconstructions (see Woodworth et al. (2009b, 2011) for an excellent synthesis of these studies). Woodworth (1990) fitted quadratic trends to long European sea level records and found little or no evidence for on-going positive sea level acceleration for the tide gauges located in the North Sea between 1870 and the late 1980 's of the sort suggested for the $20^{\text {th }}$ century itself by 
climate models (Meehl et al. 2007). These findings were confirmed by Woodworth (2009b) based on updated sea level records. However, when looking at longer time scales (two to three centuries), a significant positive acceleration can be found in most of the long European records (Woodworth et al., 2011).

The North Sea index shown in Fig. 6 contains a significant 'acceleration' (i.e. twice the quadratic coefficient of a second order polynomial fitted to the data) on the $95 \%$ confidence level of $0.013 \pm 0.002 \mathrm{~mm} / \mathrm{yr}^{2}$ for the period from 1807 to 2011 (Inner North Sea: $0.014 \pm 0.003 \mathrm{~mm} / \mathrm{yr}^{2}$ for the period 1827 to 2011 ; English Channel: $0.012 \pm 0.003 \mathrm{~mm} / \mathrm{yr}^{2}$ for the period 1807 to 2011). These 'acceleration' values are strongly related to the considered time periods. From their global sea level reconstruction, Church and White (2011) found a significant acceleration of $0.009 \pm 0.006 \mathrm{~mm} / \mathrm{yr}^{2}$ for the period from 1880 to 2009 , whereas a much smaller value of $0.001 \pm 0.005 \mathrm{~mm} / \mathrm{yr}^{2}$ is derived from the North Sea index for the same time period. However, one has to be careful interpreting these results, as different methods and data types have been used for constructing the indices. The robustness in identifying low frequency acceleration or deceleration signals by fitting quadratic trends in the presence of large inter-annual and decadal variability, and especially when focussing on relatively short time periods, has recently been critically discussed by Rahmstorf and Vermeer (2011).

Rather than using quadratic fits to identify accelerations, several authors (e.g. Church et al., 2008, Haigh et al., 2009, Albrecht et al., 2011, Wahl et al., 2011) calculated overlapping linear trends (usually for 10 to 50 -yr periods) to identify periods where sea levels have risen at high or low rates. Alternatively, different smoothing techniques, such as simple moving averages, different low pass filters or more sophisticated approaches, such as Singular Spectrum Analysis (SSA; Moore et al., 2005), have been applied to remove the variability from the sea level time series to detect inflexion points. Overall these studies have found that while the recent rates of sea level rise were high, they were not significantly higher than what has been observed at other times in the $20^{\text {th }}$ century.

Here, we use some of these described methods to investigate non-linear changes and decadal fluctuations based on the individual sea level records and the three sea level indices from the North Sea area. Fig. 10a shows 20-yr running means of the annual MSL time series for all sites (corrected for the influence of GIA, using the values in Tab. 2; mean values were calculated when at least $75 \%$ of data were available from a particular 20 -year period). All records were adjusted relative to the mean value for the 50-yr period from 1962 to 2011. It is clear from Fig. 10a, that (with the exceptions of Cuxhaven and Hoek van Holland, see discussion below) the long time series were relatively stable until the end of the $19^{\text {th }}$ century, 
before sea levels started rising throughout the $20^{\text {th }}$ century. The majority of the records also show a stable period centred around the 1960s, when almost no sea level rise occurred. The smoothed Lerwick record shows a strong downward trend after correcting for the GIA influence, suggesting that there might be something wrong with the value of $-1.0 \mathrm{~mm} / \mathrm{yr}$ (i.e. land subsidence) reported by Shennan et al. (2012) for this site. The Cuxhaven and Hoek van Holland records show a considerably different behaviour throughout the $19^{\text {th }}$ century compared to the other long records. They are not as stable as Delfzijl, Brest and (partly) Den Helder in the second half of the $19^{\text {th }}$ century. Based on the results presented here, it seems worthwhile to inspect some of the long German and Dutch records again with the aim of explaining these differences and of harmonising the data sets for the second half of the $19^{\text {th }}$ century. This could also include data sets from IJmuiden and Vlissingen before 1890, which were excluded from the study as they appear suspicious with strong downward trends in the second half of the $19^{\text {th }}$ century.

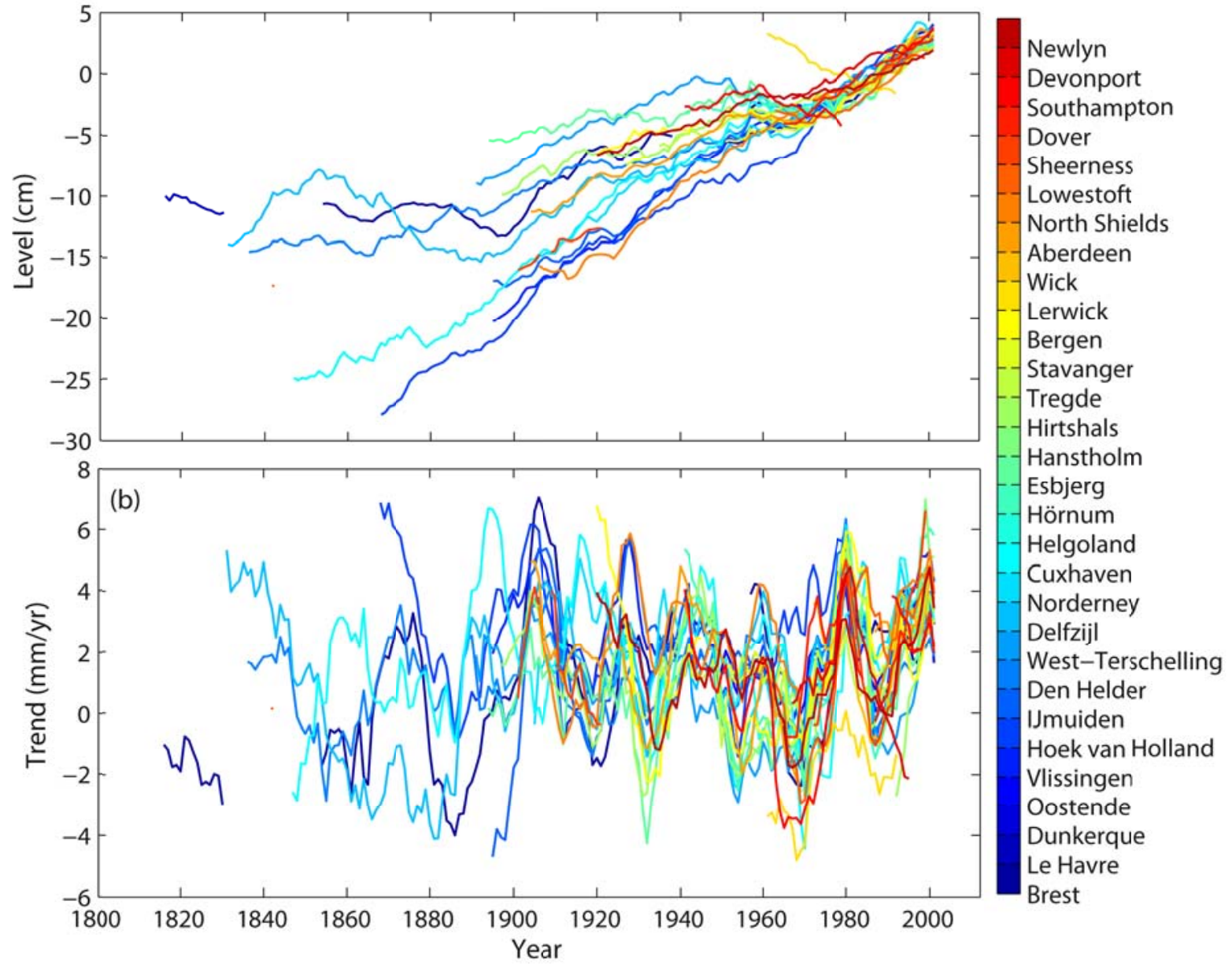

Fig. 10. (a) 20-year running means for all records, after correcting for GIA (for presenting purposes all records were adjusted to have zero mean for the 50-yr period from 1960 to 2009); (b) running 20-year linear trends for all records after correcting for GIA. 
The time series were corrected for GIA and linear trends were estimated for 20-yr moving windows and the results of this are shown in Fig. 10b. There is some coherence in the resulting time series, showing high rates of SLR around 1900 and 1980 and small rates around 1970. However, there are important differences also, highlighting that there are still local effects, influencing the decadal variability at specific sites.

In the following, we analyse the sea level indices defined earlier. The estimated AMSL trends can be added to the sea level indices and non-linear smoothing techniques can then be applied to the resulting time series to investigate regional non-linear changes. Here, we use the geocentric trends for the period from 1900 to 2011 derived after correcting for GIA, as GIA performed best in reducing the variability in the trends across the study sites in Fig. 9. Hence, the indices shown in Fig. 6a were adjusted (i.e. linear trends were added back) in a way that the resulting time series have linear trends of $1.53 \mathrm{~mm} / \mathrm{yr}$ (North Sea), $1.59 \mathrm{~mm} / \mathrm{yr}$ (Inner North Sea) and $1.18 \mathrm{~mm} / \mathrm{yr}$ (English Channel) for the period from 1900 to 2011. The resulting time series are shown in Fig. 11a. Overlaid are time series smoothed using Singular Spectrum Analysis (with an embedding dimension of 15 years) in combination with MonteCarlo-Autoregressive padding (MCAP). The technique is described in detail by Wahl et al. (2010), hence details are omitted here. The uncertainties resulting from the padding are not shown for presenting purposes, but increase when approaching the ends of the records as outlined by Wahl et al. $(2010,2011)$. Fig. $11 \mathrm{~b}$ shows the rates of change of the smoothed time series, calculated by taking the first differences (or the annual gradients) of the smoothed time series.

Both plots confirm that sea level in the North Sea has been relatively stable before an acceleration took place in the 1880's, leading to high rates of SLR throughout the first half of the $20^{\text {th }}$ century with peaks around 1900 and at the end of the 1940s. From the 1950's on the rates of SLR started decreasing, with a minimum in 1963 and started accelerating again afterwards, showing the highest values in 1999. In recent years the rates dropped to a level similar to what has been observed earlier in the $20^{\text {th }}$ century. The English Channel shows the well-known 'bump' (i.e. the rates of SLR increase abruptly from -2.8 to $4 \mathrm{~mm} / \mathrm{yr}$ ) around 1900 (Douglas, 2008) in the Brest record.

As it can be seen from Figs. 7a and 7c, the high values of SLR at the beginning of the $20^{\text {th }}$ century are obviously related to MSLP variability, whereas there are two periods, in the 1940's and over the last 20 years or so, where high values of SLR occurred and do not appear to relate to MSLP variation. Hence, there must have been other driving factors responsible for 
the high values in the 1940's and the acceleration starting in the 1970's leading to high recent rates of SLR.
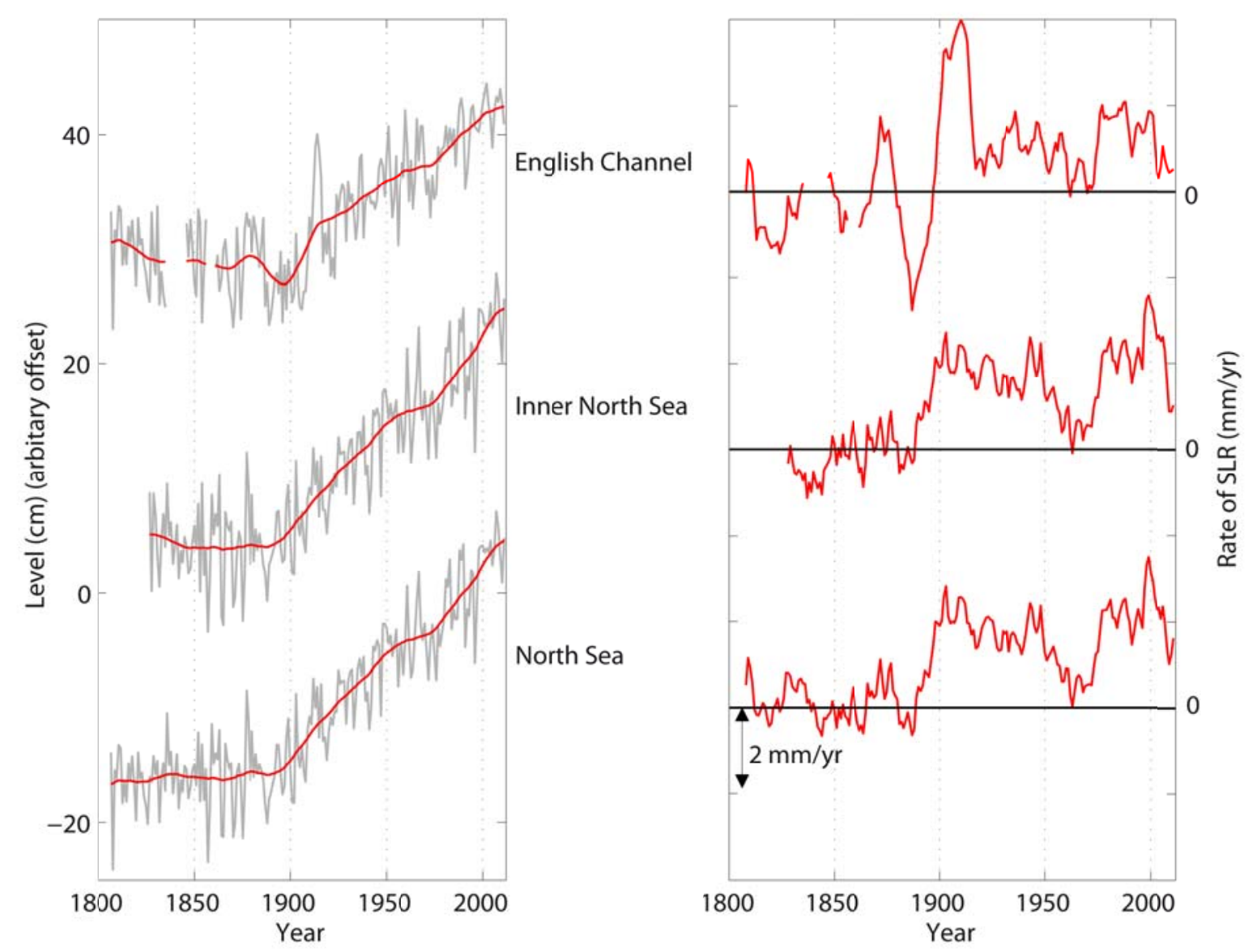

Fig. 11. (a) Time series of the three indices with estimated trends for the 1900 to 2011 period re-included (1.53, 1.59 and $1.18 \mathrm{~mm} / \mathrm{yr}$ for North Sea, Inner North Sea and English Channel) and smoothed by applying SSA with MCAP and an embedding dimension of 15 years; (b) first differences of the smoothed time series shown in (a).

Church and White (2006) also identified high rates of SLR for the period between 1930 and 1960 in a global sea level reconstruction and argued that sea level followed the more rapid global temperature rise between 1910 and 1930 (Folland et al., 2001) with a 20-year lag. From the mid 1940's to the mid 1970's global temperature has been relatively stable, before it started rising at similar rates than it did before (Folland et al., 2001). This could explain the decreasing (and small) rates of SLR in the North Sea in the 1950's and 1960's to some degree, whereas the recent acceleration started too early to be just related to global temperature changes. Chambers et al. (2012) reported that a quasi 60-year oscillation in global mean sea level could possibly play a role when interpreting the recent sea level acceleration. Hein et al. (2011) also found long-period ( $>20$ years) oscillations from analysing the 
Cuxhaven record and argued that the recent acceleration is a result of the simultaneous peaking of these multi-decadal cycles. However, the question what are the driving factors of such fluctuations remains unanswered. Miller and Douglas (2007) and Woodworth et al. (2010) found evidence that sea level measurements along the European Atlantic coast are also related to the gyre-scale circulation of the North Atlantic. Air pressure variations in the subtropical centre of the gyre were shown to be responsible, to some extent, for inflexion points detected in the considered sea level time series (e.g. in the Brest record). More recently, Sturges and Douglas (2011) and Calafat et al. $(2012,2013)$ found evidence that changes in the large-scale atmospheric forcing were responsible for the decadal sea level fluctuations observed in the $20^{\text {th }}$ century.

To sum up, the results presented here indicate that the recent rates of SLR in the North Sea are high compared to a long-term average, but with the exception of a short period around 1999, are within the range of earlier observations during the 20th century.. This confirms the results of earlier studies focussing on non-linear sea level changes in the North Sea area (i.e. Woodworth et al. 2009a; Haigh et al., 2009; Wahl et al., 2011)..

\section{Regional vs. global sea level changes}

In the following we briefly compare the observed sea level changes in the North Sea with global changes, i.e. we assess the coherency of trends, inter-annual and decadal variability. Table 3 shows AMSL trends for the three North Sea indices shown in Fig. 11 and the global reconstruction of Church and White (2011) for five different time periods. Note that the 'Global' trends listed in Tab. 3 may differ slightly from those reported by Church and White. This is due because the trends were calculated based on their reconstruction (downloaded from www.cmar.csiro.au), as Church and White (2011) do not quote trends for all five time periods considered here. Furthermore, the trends were not weighted by the uncertainties as it was done by Church and White (2011). The displayed errors are SE's with serial correlation considered. Similar to what was found from analysing the individual RMSL records, the trends are relatively consistent for the three longer time periods but are higher for the two shorter periods. The English Channel index provides an exception, as the trends are relatively consistent for all of the considered time periods. The trends derived from the North Sea and Inner North Sea indices are high compared to the global trend, especially for the 1993 to 2009 period. However, they are not significantly different; taking the large SE's associated with the inter-annual and decadal variability into account. 
Tab. 3. MSL trends for the three index time series (after correcting for GIA) and a global reconstruction (Church and White, 2011) for five common time periods

\begin{tabular}{|c|c|c|c|c|c|}
\hline Period & 1880 to 2009 & 1900 to 2009 & 1950 to 2009 & 1980 to 2009 & 1993 to 2009 \\
\hline North Sea & $1.53 \pm 0.08$ & $1.54 \pm 0.11$ & $1.62 \pm 0.29$ & $2.07 \pm 0.74$ & $4.00 \pm$ \\
\hline Inner North Sea & $1.59 \pm 0.09$ & $1.60 \pm$ & $1.71 \pm$ & $2.23 \pm$ & $4.59 \pm$ \\
\hline English Channel & $1.19 \pm$ & $1.19 \pm$ & $1.19 \pm$ & $1.28 \pm$ & $1.32 \pm$ \\
\hline Global & $1.54 \pm 0.06$ & $1.63 \pm 0.07$ & $1.80 \pm$ & $2.09 \pm 0.31$ & $2.80 \pm$ \\
\hline
\end{tabular}

Figure 12a shows that the inter-annual variability of the North Sea and global reconstructions differs considerably. The global reconstruction has a much smaller variability and the correlation between the two annual time series is strong (i.e. 0.91) when the trend is included, but negligible (i.e. 0.04) when both time series are de-trended for the overlapping period from 1880 to 2009 . The large differences in the inter-annual variability propagate to the decadal variability, which is also much smaller in the global sea level reconstruction as shown in Fig. 12b. The two time series also show a negligible correlation of -0.07 .

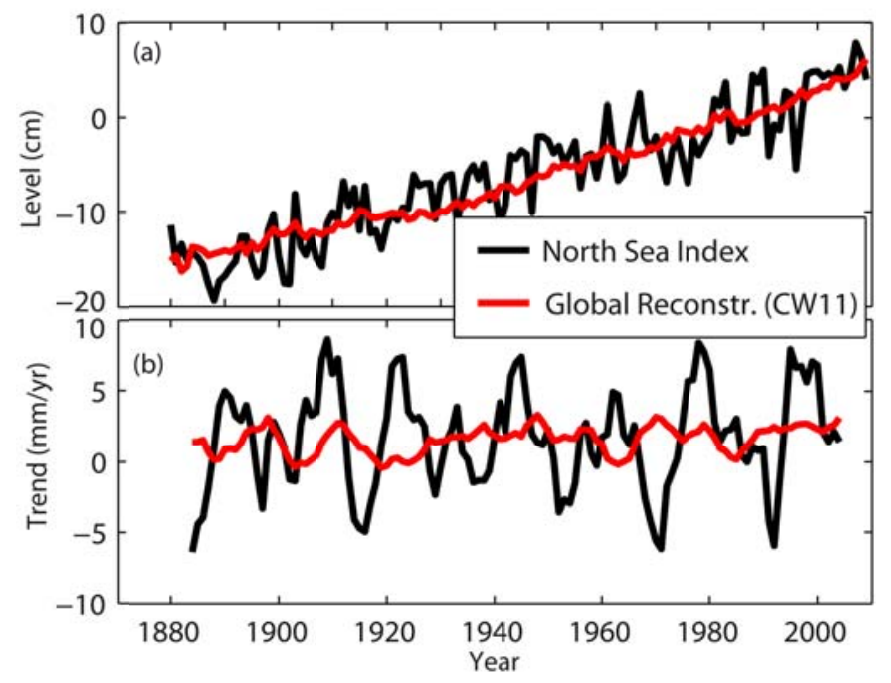

Fig. 12. (a) North Sea index and global sea level reconstruction by Church and White (2011); (b) running 10-year linear trends of the annual time series shown in (a).

In summary, the long-term trends in the North Sea are not significantly different from global sea level trends, while the inter-annual and decadal variability are much bigger in the North 
Sea and hardly comparable to those derived from the global sea level reconstruction considered here.

\section{Conclusions and recommendations}

The last detailed regional assessment of observed mean sea level changes in the North Sea was undertaken by Shennan and Woodworth (1992). Since then two more decades of tide gauge observation, additional observations from data archaeology (e.g., Southampton) (Haigh et al., 2009) and new measurements of sea level from satellite altimeters have become available. Furthermore, advanced models and geodetic techniques now allow a more accurate separation of AMSL and RMSL changes. This paper has made use of these updated sea level records from 30 tide gauges covering the entire North Sea coastline, gridded altimetry and mean sea level pressure (MSLP) data sets and vertical land movement information derived with a range of different methods to examine the observed mean sea level changes in the North Sea over the last 200 years.

Focussing first on relative sea level changes, we found that the linear trends for common time periods vary across the 30 study sites and are broadly consistent with known vertical land movement patterns. The year-to-year sea level variability is much larger along the coastlines of Belgium, the Netherlands, Germany and Denmark compared to Norway, the UK east coast and the English Channel and this influences the uncertainty associated with the trend estimates. Part of the variability is coherent across the region, but with some differences between the Inner North Sea and the English Channel. This coherence was analysed further by constructing 'sea level indices' for the entire North Sea, the Inner North Sea and the English Channel from the individual sites in the particular regions. The decadal variability in the North Sea sea level index was correlated to a North Sea MSLP index, highlighting that some inflexion points in the sea level time series were driven by MSLP variations. In the English Channel and along the Norwegian, the northernmost UK and northern Denmark coastlines large parts of the observed sea level variability were also driven by MSLP variations. Other forcing factors, such as local winds, precipitation or river run-off, have larger influences on sea level variability in the remaining areas.

While relative sea level changes are the primary concern for coastal planners and managers, the non-climate contribution of vertical land movement and GIA induced changes in the geoid of the ocean need to be removed from the data sets to investigate the climatedriven component of long-term sea level changes. Here, information on vertical land 
movement derived from GIA models, geological studies, CGPS measurements and from comparing tide gauge and altimetry records were considered to correct the relative sea level time series. Although broadly consistent in terms of the land movement direction (i.e. uplift or subsidence), the magnitudes of the different estimates of VLM rates vary significantly across the methods at some sites. The linear trends across the study sites were most consistent after correcting observed RMSL time series with predicted RMSL rates from a GIA model. The results highlight that the local rates of vertical land movement at the tide gauge sites remain uncertain. However, this situation is steadily improving as the lengths of CGPS records increase (and more tide gauges are equipped with CGPS antenna) and the accuracy of altimeter products in the coastal zone improve. These improvements will advance our understanding of geocentric sea level changes in the future.

Here, the long-term AMSL trend for the 1900 to 2011 period was determined to be $1.53 \pm 0.16 \mathrm{~mm} / \mathrm{yr}$ for the entire North Sea region. It is slightly higher for the Inner North Sea (i.e. $1.59 \pm 0.16 \mathrm{~mm} / \mathrm{yr}$ ) and smaller (although not significantly different) for the English Channel (i.e. $1.18 \pm 0.16 \mathrm{~mm} / \mathrm{yr}$ ). In general these results are consistent with those presented by Woodworth et al. (2009a), who estimated the geocentric component of sea level rise to be $1.4 \pm 0.2 \mathrm{~mm} / \mathrm{yr}$ for the $20^{\text {th }}$ century from a few long UK tide gauge records.

Periods of sea level rise acceleration (i.e. at the end of the $19^{\text {th }}$ century and in the 1970's) and deceleration (i.e. in the 1950's/1960's) were evident in the tide gauge time series. The recent rates of sea level rise are considerably higher, with the highest rates at the end of the $20^{\text {th }}$ century, but are still of the same order of magnitude to those which have been observed at earlier times in the $19^{\text {th }}$ and $20^{\text {th }}$ century. Long-term sea level trends in the North Sea are similar to global long-term trends, but are higher for the last few decades compared to the global mean. However, these differences between regional and global sea level rise are not yet statistically significant as the uncertainties also increase when considering shorter time periods.

In terms of the expected $21^{\text {st }}$ century sea level rise rates, the observed long-term trends in the North Sea do not show any evidence yet that regional sea level changes will differ significantly from the projected global changes. Thus, it seems justified to take global scenarios (e.g., Meehl et al., 2007) as a basis for deriving reliable regional or local relative SLR scenarios, as required for coastal planning and management purposes. Importantly, these scenarios must consider the influence of vertical land movement and other regional effects, which could potentially amplify the future flood risk for certain areas (e.g. Lowe et al., 2009; Katsmann et al., 2008, 2011; Slangen et al., 2012). 
In terms of assessing flood risk, it is important to compare changes in extreme sea levels with the observed mean sea level changes discussed in this present paper. Several global (e.g. Menéndez and Woodworth, 20110) and more detailed studies (e.g. Araújo and Pugh, 2008; Haigh et al., 2010; Dangendorf et al., accepted) have dealt with this topic, but a detailed regional assessment for the North Sea has not been undertaken to date. The mean sea level time series from the 30 tide gauges considered in the present study could be compared to extreme sea level data sets at the same sites. To derive reliable results from such a project or related studies, and to improve our understanding of regional sea level patterns, collaboration between all North Sea states is required. A first step in this direction has been taken by the European Climate Research Alliance in developing a 'Collaborative Programme on the Regional Aspects of Sea Level Change' (for more information see: http://www.ecraclimate.eu). Larger scale assessments including data from the British Isles and the European northeast Atlantic coastline (i.e. from northern Norway to Gibraltar) would furthermore help to improve our understanding of the interaction between the Atlantic and the North Sea.

\section{Acknowledgements}

We thank the SONEL group (www.sonel.org.) for delivering results from the latest CGPS survey at an early stage (before it was released on their website), the PSMSL for providing sea level and related data sets, Vibeke Huess from the Danish Meteorological Institute for providing raw data to update the Danish tide gauges at an early stage (meanwhile updated data sets are also available from PSMSL), the German Waterways and Shipping Administration and the Federal Institute of Hydrology for providing raw data sets to update the German tide gauges and AVISO and NOAA for providing altimetry and reanalysis products, respectively. Sönke Dangendorf assisted in updating some of the tide gauge records and provided helpful comments on an early draft of the manuscript. T.W. and I.D.H. were partially funded by the German Academic Exchange Service (DAAD) and the Group of Eight Ltd., as part of the Group of Eight Australia-Germany Joint Research Cooperation Scheme. We appreciate the suggestions made by two anonymous reviewers and the handling editor; they greatly improved the paper.

\section{References}

Albrecht, F., Wahl, T., Jensen, J., Weisse, R., 2011. Determining Sea Level change in the German Bight. Ocean Dynamics 61 (12), 2037-2050. 
Albrecht, F., Weisse, R., 2012. Pressure effects on past regional sea level trends and variability in the German Bight. Ocean Dynamics 62 (8), 1169-1186.

Araújo, I., 2005. Sea level variability: Examples from the Atlantic coast of Europe. Ph.D. Thesis, University of Southampton, United Kingdom, 216 pp.

Araújo, I., Pugh, D.T., 2008. Sea levels at Newlyn 1915-2005: Analysis of trends for future flooding risks. Journal of Coastal Research 24 (sp3), 203-212.

Aunan, K., Romstad, B., 2008. Strong Coasts and Vulnerable Communities: Potential Implications of Accelerated Sea-Level Rise for Norway. Journal of Coastal Research 24 (2), 403-409.

Bouin, M.N., Wöppelmann, G., 2010. Land motion estimates from GPS at tide gauges: A geophysical evaluation. Geophysical Journal International 180, 193-209. http://dx.doi.org/10.1111/j.1365-246X.2009.04411.x.

Bradley, S., Milne, G.A., Teferle, F.N., Bingley, R.M., Orliac, E.J., 2009. Glacial isostatic adjustment of the British Isles: New constraints from GPS measurements of crustal motion. Geophysical Journal International. http://dx.doi.org/10.1111/j.1365-246x.2008.04033.x.

Bungenstock, F., Schäfer, A., 2009. The Holocene relative sea-level curve for the tidal basin of the barrier island Langeoog, German Bight, Southern North Sea. Global and Planetary Change 66 (1-2), 34-51.

Calafat, F.M., Chambers, D.P., Tsimplis, M.N., 2012. Mechanisms of decadal sea level variability in the Eastern North Atlantic and the Mediterranean Sea. J. Geophys. Res., 117. http://dx.doi.org/10.1029/2012JC008285.

Calafat, F.M., Chambers, D.P., Tsimplis, M.N., 2013. Inter-annual to decadal sea-level variability in the coastal zones of the Norwegian and Siberian Seas: The role of atmospheric forcing. J. Geophys. Res. Oceans, 118. doi:10.1002/jgrc.20106.

Cazenave, A., Dominh, K., Ponchaut, F., Soudarin, L., Crétaux, J.F., Le Provost, C., 1999. Sea level changes from TOPEX-POSEIDON altimetry and tide gauges, and vertical crustal motions from DORIS, Geophys. Res. Lett. 26, 2077-2080. http://dx.doi.org/10.1029/1999GL900472. 
Chambers, D.P., Merrifield, M.A., Nerem, R.S., 2012. Is there a 60-year oscillation in global mean sea level?, Geophys. Res. Lett. 39, L18607. http://dx.doi.org/10.1029/2012GL052885.

Church, J.A., White, N.J., 2006. A 20th century acceleration in global sea-level rise. Geophys. Res. Lett. 33, L01602. http://dx.doi.org/10.1029/2005GL024826.

Church, J.A., White, N.J., Aarup, T., Wilson, S.W., Woodworth, P.L., Domingues, C.M., Hunter, J.R., Lambeck, K., 2008. Understanding global sea levels: past, present and future. Sustainability Sci. 3, 9-22. http://dx.doi.org/10.1007/s11625-008-0042-4.

Church, J.A., White, N.J., 2011. Sea-level rise from the late 19th to the early 21 st Century. Surveys in Geophysics 32, 585-602. http://dx.doi.org/10.1007/s10712-011-9119-1D.

Compo, G.P., Whitaker, J.S., Sardeshmukh, P.D., Matsui, N., Allan, R.J., Yin, X., Gleason, B.E., Vose, R.S., Rutledge, G., Bessemoulin, P., Brönnimann, S., Brunet, M., Crouthamel, R.I., Grant, A.N., Groisman, P.Y., Jones, P.D., Kruk, M., Kruger, A.C., Marshall, G.J,. Maugeri, M., Mok, H.Y., Nordli, Ø., Ross, T.F., Trigo, R.M., Wang, X.L., Woodruff, S.D., Worley, S.J., 2011. The Twentieth Century Reanalysis Project. Quarterly J. Roy. Meteorol. Soc. 137, 1-28. http://dx.doi.org/10.1002/qj.776.

Dangendorf, S., Wahl, T., Hein, H., Jensen, J., Mai, S., Mudersbach, C., 2012. Mean Sea Level Variability and Influence of the North Atlantic Oscillation on Long-Term Trends in the German Bight. Water 4 (1), 170-195.

Dangendorf, S., Muderbach, C., Wahl, T., Jensen, J., 2013. Characteristics of intra-, interannual and decadal variability and the role of meteorological forcing: The long record of Cuxhaven. Ocean Dynamics, 63 (2-3), pp. 209-224.

Dangendorf, S., Mudersbach, C., Jensen, J., Ganske, A., Heinrich, H. Seasonal to decadal forcing of high sea level percentiles in the German Bight throughout the last century, Ocean Dynamics 63, 5, 533-548, DOI 10.1007/s10236-013-0614-4.

de la Vega-Leinert, A.C., Nicholls, R.J., 2008. Potential Implications of Sea-Level Rise for Great Britain. Journal of Coastal Research 24 (2), 342-357. http://dx.doi.org/10.2112/07A0008.1 .

Dillingh, D., Fedor, B., de Ronde, J., 2010. Definitie zeespiegelstijging voor bepaling suppletiebehoefte, Deltares report 1201993-002, Delft. 
Douglas, B.C., 1991. Global sea level rise. Journal of Geophysical Research 96 (C4), 69816992.

Douglas, B.C., 2008. Concerning evidence for fingerprints of glacial melting. Journal of Coastal Research 24 (sp2), 218-227.

Fenger, J., Buch, E., Jakobsen, P.R., Vestergaard, P., 2008. Danish attitudes and reactions to the threat of sea-level rise. Journal of Coastal Research 24 (2), 394-402.

Folland, C.K., Karl, T.R., Christy, J.R., Clarke, R.A., Gruza, G.V., Jouzel, J., Mann, M.E., Oerlemans, J., Salinger, M.J., Wang, S.-W., 2001. Observed Climate Variability and Change. pp. 99-181. In: Houghton, J.T., Ding, Y., Griggs, D.J., Noguer, M., van der Linden, P.J., Dai, X., Maskell, K., Johnson, C.A. (Editors), Climate Change 2001: The Scientific Basis. Contribution of Working Group I to the Third Assessment Report of the Intergovernmental Panel on Climate Change, Cambridge University Press, Cambridge, UK, $881 \mathrm{pp}$.

Garcia, D., Vigo, I., Chao, B.F., Martinez, M.C., 2007. Vertical crustal motion along the Mediterranean and Black Sea coast derived from ocean altimetry and tide gauge data. Pure appl. geophys. 164, 851-863.

Gehrels, R., 2006. Sea-level rise and coastal subsidence in southwest England. Reports and Transactions of the Devonshire Association 138, 25-42.

Gehrels, W.R., Woodworth, P.L., 2012. When did modern rates of sea-level rise start? Global and Planetary Change. http://dx.doi.org/10.1016/j.gloplacha.2012.10.020.

González, M., Almudena, F., Ganix, E., Collins, M., 2013. Abrupt changes, multidecadal variability and long-term trends in sea surface temperature and sea level datasets within the southeastern Bay of Biscay. Journal of Marine Systems, 109-110, S144-S152. (doi:10.1016/j.jmarsys.2011.11.014).

Grinsted, A., Moore, J.C., Jevrejeva, S., 2009. Reconstructing sea level from paleo and projected temperatures 200 to 2100 AD, Clim Dyn., published online first. http://dx.doi.org/10.1007/s00382-008-0507-2.

Haigh, I.D., 2009. Extreme sea levels in the English Channel 1900 to 2006. Ph.D. Thesis, University of Southampton, United Kingdom, 198 pp. 
Haigh, I.D., Nicholls, R.J., Wells, N.C., 2009. Mean sea-level trends around the English Channel over the 20th century and their wider context. Continental Shelf Research 29, 2083-2098.

Haigh, I., Nicholls, R., Wells, N., 2010. Assessing changes in extreme sea levels: Application to the English Channel, 1900-2006, Continental Shelf Research 9, 1042-1055. http://dx.doi.org/10.1016/j.csr.2010.02.002.

Hamlington, B.D., Leben, R.R., Nerem, R.S., Han, W., Kim, K.-Y., 2011. Reconstructing sea level using cyclostationary empirical orthogonal functions. J. Geophys. Res. 116, C12015. http://dx.doi.org/10.1029/2011JC007529.

Hansen, J.M., Aagaard, T., Binderup, M., 2011. Absolute sea levels and isostatic changes of the eastern North Sea to central Baltic region during the last 900 years. Boreas 41 (2).

Hanson, S., Nicholls, R., Ranger, N., Hallegatte, S., Corfee-Morlot, J., Herweijer, C., Chateau, J., 2011. A global ranking of port cities with high exposure to climate extremes. Clim. Change, 104, 89-111.

Hein, H., Mai, S., Barjenbruch, U., 2011. What tide gauges reveal about the future sea level, Proc. of the Aqua Alta, Hamburg.

Holgate, S.J., 2007. On the decadal rates of sea level change during the twentieth century, Geophys. Res. Lett. 34, L01602. http://dx.doi.org/10.1029/2006GL028492.

Jensen, J., Hofstede, J., Kunz, H., De Ronde, J., Heinen, P., Siefert, W., 1993. Long Term Water Level Observations and Variations. Coastal Zone '93, Special Volume "Coastlines of the Southern North Sea".

Jevrejeva, S., Grinsted, A., Moore, J.C., Holgate, S., 2006. Nonlinear trends and multiyear cycles in sea level records. J. Geophys. Res. 111, C09012. http://dx.doi.org/10.1029/2005JC003229.

Jevrejeva, S., Moore, J.C., Grinsted, A., Woodworth, P.L., 2008. Recent global sea level acceleration started over 200 years ago?, Geophys. Res. Lett. 35, L08715, http://dx.doi.org/10.1029/2008GL033611.

Katsman, C.A., Hazeleger, W., Drijfhout, S.S., van Oldenborgh, G.J., Burgers, G.J.H., 2008. Climate scenarios of sea level rise for the northeast Atlantic Ocean: a study including the 
effects of ocean dynamics and gravity changes induced by ice melt. Climatic Change, 91: 3-4, 351-374.

Katsman, C.A., Sterl, A., Beersma, J.J., van den Brink, H.W., Hazeleger, W. and 15 coauthors, 2011. Exploring high-end scenarios for local sea level rise to develop flood protection strategies for a low-lying delta - the Netherlands as an example. Climatic Change. http://dx.doi.org/10.1007/s10584-011-0037-5.

King, M. A., Keshin, M., Whitehouse, P.L., Thomas, I.D., Milne, G., Riva, R.E.M., 2012. Regional biases in absolute sea-level estimates from tide gauge data due to residual unmodeled vertical land movement. Geophys. Res. Lett. 39, L14604. http://dx.doi.org/10.1029/2012GL052348.

Kolker, A.S., Hameed, S., 2007. Meteorogically driven trends in sea level rise. Geophys. Res. Lett. 34. http://dx.doi.org/10.1029/2007GL031814.

Kuo, C.Y., Shum, C.K., Braun, A., Mitrovica, J.X., 2004. Vertical crustal motion determined by satellite altimetry and tide gauge data in Fennoscandia. Geophys. Res. Lett. 31, L01608. http://dx.doi.org/10.1029/2003GL019106.

Lamb H., 1991. Historic storms of the North Sea, British Isles and Northwest Europe. Cambridge University Press, Cambridge, 204 pp.

Lavery, S., Donovan, B., 2005. Flood risk management in the Thames Estuary looking ahead 100 years. Phil. Trans. R. Soc. A. 363, 1455-1474. http://dx.doi.org/10.1098/rsta.2005.1579.

Lebbe, L., Van Meir, N., Viaene, P., 2008. Potential implications of sea-level rise for Belgium. Journal of Coastal Research 24 (2), 358-366.

Lowe, J.A., Howard, T.P., Pardaens, A., Tinker, J., Holt, J., Wakelin, S., Milne, G., Leake, J., Wolf, J., Horsburgh, K., Reeder, T., Jenkins, G., Ridley, J., Dye, S., Bradley, S., 2009. UK Climate Projections science report: Marine and coastal projections. Met Office Hadley Centre, Exeter, UK.

Madsen, K.S., Høyer, J.L., Tscherning, C.C., 2007. Near-coastal satellite altimetry: Sea surface height variability in the North Sea-Baltic Sea area. Geophys. Res. Lett. 34, L14601, http://dx.doi.org/10.1029/2007GL029965. 
Madsen, K.S., 2009. Recent and future climatic changes in temperature, salinity, and sea level of the North Sea and the Baltic Sea. PhD thesis, Niels Bohr Institute, University of Copenhagen.

McRobie, A., Spencer, T. Gerritsen, H., 2005. The Big Flood: North Sea storm surge. Philosophical Transactions of the Royal Society A. 363, 1261-1491.

Meehl, G.A., Stocker, T.F., Collins, W.D., Friedlingstein, P., Gaye, A.T., Gregory, J.M., Kitoh, A., Knutti, R., Murphy, J.M., Noda, A., Raper, S.C.B., Watterson, I.G., Weaver, A.J., Zhao, Z.-C., 2007. Global Climate Projections. In: Solomon, S., Qin, D., Manning, M., Chen, Z., Marquis, M., Averyt, K.B., Tignor, M., Miller, H.L. (Editors), Climate Change 2007: The Physical Science Basis. Contribution of Working Group I to the Fourth Assessment Report of the Intergovernmental Panel on Climate Change Cambridge University Press, Cambridge, United Kingdom and New York, NY, USA.

Menéndez. M., Woodworth, P.L., 2010. Changes in extreme high water levels based on a quasi-global tide-gauge dataset, J. Geophys. Res. 115, C10011. http://dx.doi.org/10.1029/2009JC005997.

Miller, L., Douglas, B.C., 2007. Gyre-scale atmospheric pressure variations and their relation to 19th and 20th century sea level rise. Geophys. Res. Lett. 34, L16602. http://dx.doi.org/10.1029/2007GL030862.

Milne, G.A., Gehrels, W.R., Hughes, C.W., Tamisiea, M.E., 2009. Identifying the causes of sea-level change. Nat. Geosci. 2, 471-478.

Moore, J.C., Grinsted, A., Jevrejeva, S., 2005. The new tools for analyzing the time series relationships and trends, Eos Trans. AGU 86 (24), 226-232.

Munich Re, 2012. Press Dossier. Online available at http://www.munichre.com/app_pages/www/@res/pdf/media_relations/press_dossiers/50thanniversary-storm-surge-hamburg/50th-anniversary-of-the-north-sea-flood-of-hamburgen.pdf.

Nerem, R.S., Mitchum, G.T., 2002. Estimates of vertical crustal motion derived from differences of TOPEX/POSEIDON and tide gauge sea level measurements. Geophys. Res. Lett. 29 (19). http://dx.doi.org/10.1029/2002GL015037. 
Nicholls, R.J., Wong, P.P., Burkett, V.R., Codignotto, J.O., Hay, J.E., McLean, R.F., Ragoonaden, S.,Woodroffe, C.D., 2007. Coastal systems and low-lying areas. In: Parry, M.L., Canziani, O.F., Palutikof, J.P., van der Linden, P.J., Hanson, C.E. (Eds.), Climate Change 2007: Impacts, Adaptation and Vulnerability. Contribution of Working Group II to the Fourth Assessment Report of the Intergovernmental Panel on Climate Change. Cambridge University Press, Cambridge, United Kingdom and New York, NY, USA, pp. $315-356$.

Nicholls, R.J., Cazenave, A., 2010. Sea-Level Rise and Its Impact on Coastal Zones, Science 328 (5985), 1517-1520. http://dx.doi.org/10.1126/science.1185782.

Nicholls, R.J., Hanson, S.E., Lowe, J.A., Warrick, R.A., Lu, X., Long, A.J., Carter, T.R., 2011. Constructing Sea-Level Scenarios for Impact and Adaptation Assessment of Coastal Area: A Guidance Document. Supporting Material, Intergovernmental Panel on Climate Change Task Group on Data and Scenario Support for Impact and Climate Analysis (TGICA), 47 pp. Available online at http://www.ipccdata.org/docs/Sea_Level_Scenario_Guidance_Oct2011.pdf.

Nilsen, J.E.Ø., Drange, H., Richter, K., Jansen, E., Nesje, A., 2012. Changes in the past, present, and future sea level on the coast of Norway. NERSC Special Report 89, Bergen, Norway, $48 \mathrm{pp}$.

Paskoff, R., 2004. Potential implications of sea-level rise for France. Journal of Coastal Research 20 (2), 424-434.

Peltier, W.R., 2001. Global glacial isostatic adjustment and modern instrumental records of relative sea level history. In: Douglas, B.C., Kearney, M.S., Leatherman, S.P. (Editors), Sea Level Rise: History and Consequences Vol. 75, Academic Press, San Diego, CA, pp. $65-95$.

Peltier, W.R., 2004. Global Glacial Isostasy and the Surface of the Ice-Age Earth: The ICE5G(VM2) model and GRACE. Ann. Rev. Earth. Planet. Sci. 32, 111-149. http://dx.doi.org/10.1146/annurev.earth.32.082503.144359.

Pfeffer, W., Harper, J. O’Neel, S., 2008. Kinematic constraints on glacier contributions to 21st-century sea-level rise. Science 321, 1340-1343. 
Rahmstorf, S., 2007. A Semi-Empirical Approach to Projecting Future Sea-Level Rise, Science 315 (5810), 368-370. http://dx.doi.org/10.1126/science.1135456.

Rahmstorf, S., Vermeer, M., 2011. Discussion of: Houston, J.R. and Dean, R.G., 2011. SeaLevel Acceleration Based on U.S. Tide Gauges and Extensions of Previous Global-Gauge Analyses. Journal of Coastal Research, 27 (3), 409-417.

Ray, R., Beckley, B., Lemoine, F., 2010. Vertical crustal motion derived from satellite altimetry and tide gauges, and comparisons with DORIS measurements. Advances in Space Research 45, 1510-1522.

Ray, R.D., Douglas, B.C., 2011. Experiments in reconstructing twentieth-century sea levels. Progress in Oceanography 91, 496-515.

Richter, K., Nilsen, J.E.Ø., Drange, H., 2012. Contributions to sea level variability along the Norwegian coast for 1960-2010. Journal of Geophysical Research 117, C05038. http://dx.doi.org/10.1029/2011JC007826.

Rohling, E., Grant, K., Hemleben, C., Siddall, M., Hoogakker, B., Bolshaw, M., Kucera, M., 2008. High rates of sea-level rise during the last interglacial period. Nat. Geosci. 1, 38-42., doi:10.1038/ngeo.2007.28.

Santamaría-Gómez, A., Gravelle, M., Collilieux, X., Guichard, M., Martín Míguez, B., Tiphaneau, P., Wöppelmann, G., 2012. Mitigating the effects of vertical land motion in tide gauge records using a state-of-the-art GPS velocity field. Global and Planetary Change 98-99, 6-17. http://dx.doi.org/10.1016/j.gloplacha.2012.07.007.

Santer, B.D., Wigley, T.M.L., Boyle, J.S., Gaffen, D.J., Hnilo, J.J., Nychka, D., Parker, D.E., Taylor, K.E., 2000. Statistical significance of trends and trend differences in layer average atmospheric temperature time series, J. Geophys. Res., 105, 7337- 7356.

Schöne, T., Schön, N., Thaller, D., 2009. IGS Tide Gauge Benchmark Monitoring Pilot Project (TIGA): scientific benefits. Journal of Geodesy 83, 249-261. http://dx.doi.org/10.1007/s00190-008-0269-y.

Shennan, I., Woodworth, P.L., 1992. A comparison of late Holocene and twentieth century sea-level trends from the UK and North Sea region. Geophys. J. Int. 109, 96-105. 
Shennan, I., Horton, B.P., 2002. Holocene land- and sea-level changes in Great Britain. Journal of Quaternary Science 17, 511-526.

Shennan, I., Milne, G., Bradley, S., 2012. Late Holocene vertical land motion and relative sea-level changes: lessons from the British Isles. Journal of Quarternary Science 27 (1), 64-70.

Simpson, M., Breili, K., Kierulf, H.P., Lysaker, D., Ouassou, M., Haug, E., 2012. Estimates of Future Sea-Level Changes for Norway. Technical Report of the Norwegian Mapping Authority.

Slangen, A.B.A., Katsman, C.A., van de Wal, R.S.W., Vermeersen, L.L.A., Riva, R.E.M., 2012. Towards regional projections of twenty-first century sea-level change based on IPCC SRES scenarios. Clim. Dynam.. http://dx.doi.org/10.1007/s00382-011-1057-6.

Sterr, H., 2008. Assessment of vulnerability and adaptation to sea-level rise for the coastal zone of Germany. Journal of Coastal Research 24 (2), 380-393.

Stive, M.J.F., Fresco, L.O., Kabat, P., Parmet, B.W.A.H., Veerman, C.P., 2011. How the Dutch plan to stay dry over the next century. Proceedings of Institution of Civil Engineers $164,114-121$.

Sturges, W., Douglas, B.C., 2011. Wind effects on estimates of sea level rise. J. Geophys. Res. 116, C06008. http://dx.doi.org/10.1029/2010JC006492.

Tamisiea, M.E., 2011. Ongoing glacial isostatic contributions to observations of sea level change. Geophysical Journal International $186 \quad$ (3), 1036-1044. http://dx.doi.org/10.1111/j.1365-246X.2011.05116.x.

Tamisiea, M.E., Mitrovica, J.X., 2011. The moving boundaries of sea level change: Understanding the origins of geographic variability. Oceanography 24 (2), 24-39. http://dx.doi.org/10.5670/oceanog.2011.25.

Teferle, F.N., Bingley, R.M., Orliac, E.J., Williams, S.D.P., Woodworth, P.L., McLaughlin, D., Baker, T.F., Shennan, I., Milne, G.A., Bradley, S.L., Hansen, D.N., 2009. Crustal motions in Great Britain: evidence from continuous GPS, absolute gravity and Holocene sea level data. Geophysical Journal International 178, 23-46. 
Tooley, M. J., 1982. Introduction: IGCP Project No. 61, Sea-level movements during the last deglacial hemicycle (about 15,000 years). Proc. geol. Ass., 93, 3-6.

Tsimplis, M.N., Spencer, N.E., 1997. Collection and analysis of monthly mean sea level data in the Mediterranean and the Black Sea. Journal of Coastal Research 13, 534-544.

Tsimplis, M.N., Woolf, D.K., Osborn, T.J., Wakelin, S., Wolf, J., Flather, R., Shaw, A.G.P., Woodworth, P.L., Challenor, P., Blackmen, D., Pert, F., Yan, Z., Jevrejeva, S., 2005. Towards a vulnerability assessment of the UK and Northern European coasts; the role of regional climate variability. Philos. Trans. R. Soc. A. 363, 1329-1358.

Tsimplis, M.N., Shaw, A.G.P., Flather, R.A., Woolf, D.K., 2006. The influence of the North Atlantic Oscillation on the sea-level around the northern European coasts reconsidered: the thermosteric effects. Philosophical Transactions of the Royal Society of London A 364, $845-856$.

Van Cauwenberghe, C., 1995. Relative sea level rise: further analyses and conclusions with respect to the high water, the mean sea and the low water levels along the Belgian coast, Report 37 of the Hydrografische Dienst der Kust.

Van Cauwenberghe, C., 1999. Relative sea level rise along the Belgian coast: analyses and conclusions with respect to the high water, the mean sea and the low water levels, Report 46 of the Hydrografische Dienst der Kust.

Van Koningsveld, M., Mulder J.P.M., Stive, M.J.F., Van Der Valk, L., Van Der Weck, A.W., 2008. Living with sea level rise and climate change: a case study of the Netherlands, Journal of coastal research 24 (2), 367-379.

Vellinga, P., Katsman, C.A., Sterl, A., Beersma, J.J., Church, J.A., Hazeleger, W., Kopp, R.E., Kroon, D., Kwadijk, J., Lammersen, R., Lowe, J., Marinova, N., Oppenheimer, M., Plag, H.P., Rahmstorf, S., Ridley, J., von Storch, H., Vaughan, D.G., van der Wal, R.S.W., Weisse, R., 2008. Exploring high- end climate change scenarios for flood protection of The Netherlands, International scientific assessment carried out at request of the delta committee. Scientific Report WR-2009-05, KNMI/Alterra, The Netherlands.

Vermeer, M., Rahmstorf, S., 2009. Global sea level linked to global temperature. http://dx.doi.org/10.1073/pnas.0907765106. 
Verwaest, T., Viaene, P., Verstraeten, J., Mostaert, F., 2005. De zeespiegelstijging meten, begrijpen en afblokken, De Grote Rede 15, 15-25.

Vignudelli S., Kostianoy A. G., Cipollini P., Benveniste J. (Editors), 2011.: Coastal Altimetry, Springer-Verlag Berlin Heidelberg, 578 pp. http://dx.doi.org/10.1007/978-3642-12796-0.

Wahl, T., Jensen, J., Frank, T., 2010. On analysing sea level rise in the German Bight since 1844. Nat. Hazards Earth Syst. Sci. 10, 171-179. http://dx.doi.org/10.5194/nhess-10-1712010 .

Wahl, T., Jensen, J., Frank, T., Haigh, I.D., 2011. Improved estimates of mean sea level changes in the German Bight over the last 166 years. Ocean Dynamics 61 (5), 701-715. http://dx.doi.org/10.1007/s10236-011-0383-x.

Wakelin, S.L., Woodworth, P.L., Flather, R.A., Williams, J.A., 2003. Sea-level dependence on the NAO over the NW European continental shelf. Geophys. Res. Lett. 7, 56:1-56:4.

Wilby, R., Nicholls, R.J., Warren, R., Wheater, H., Clarke, D., Dawson, R., 2011. New nuclear build: adaptation options over the full life-cycle. Proceedings of Institution of Civil Engineers 164, 129-136.

Woodworth, P.L., 1987. Trends in U.K. mean sea level. Marine Geodesy 11, 57-87.

Woodworth, P.L., 1990. A search for accelerations in records of European mean sea level. International Journal of Climatology 10, 129-143.

Woodworth, P.L., 2006. Some important issues to do with long-term sea level change. Phil. Trans. R. Soc. A 364, 787-803. http://dx.doi.org/10.1098/rsta.2006.1737.

Woodworth, P.L., Pugh, D. T., De Ronde, J. G., Warrick, R. G., Hannah, J. (Editors), 1992. Sea Level Changes: Determination and Effects. Geophys. Monogr. Ser. 69, AGU, Washington, D.C., 208 pp..

Woodworth, P.L., Tsimplis, M.N., Flather, R.A., Shennan, I., 1999. A review of the trends observed in British Isles mean sea level data measured by tide gauges. Geophysical Journal International $136(3), 651-670$. 
Woodworth, P.L., Player, R., 2003. The Permanent Service for Mean Sea Level: an update to the 21 st century. J. Coast. Res. 19, 287-295.

Woodworth, P.L., Teferle, F.N., Bingley, R.M., Shennan, I., Williams, S.D.P., 2009a. Trends in UK mean sea level revisited. Geophys. J. Int. 176 (22), 19-30. http://dx.doi.org/10.1111/j.1365-246X.2008.03942.x.

Woodworth, P.L., White, N.J., Jevrejeva, S., Holgate, S.J., Gehrels, W.R., 2009b. Evidence for the accelerations of sea level on multi-decade and century timescales. In: International Journal of Climatology. http://dx.doi.org/10.1002/joc.1771.

Woodworth, P.L., Pouvreau, N., Wöppelmann, G., 2010. The gyre-scale circulation of the North Atlantic and sea level at Brest. Ocean Sci. 6, 185-190. http://dx.doi.org/10.5194/os6-185-2010.

Woodworth, P.L., Menéndez, M., Roland Gehrels, W., 2011. Evidence for Century-Timescale Acceleration in Mean Sea Levels and for Recent Changes in Extreme Sea Levels, Surveys in Geophysics, 1-16.

Woolf, D.K., Shaw, A.G.P., Tsimplis, M.N., 2003. The influence of the North Atlantic Oscillation on sea level variability in the North Atlantic Region. Global Atmos. Ocean Sys. $9(4), 145-167$.

Wöppelmann,G., Pouvreau, N., Simon, B., 2006. Brest sea level record: A time series construction back to the early eighteenth century. Ocean Dynamics 56 (5-6), 487-497. http://dx.doi.org/10.1007/s10236-005-0044-z.

Wöppelmann, G., Miguez, B.M., Bouin, M.-N., Altamimi, Z., 2007. Geocentric sea-level trend estimates from GPS analyses at relevant tide gauges world-wide. Global and Planetary Change 57, 369-406.

Wöppelmann, G., Pouvreau, N., Coulomb, A., Simon, B., Woodworth, P.L., 2008. Tide gauge datum continuity at Brest since 1711: France's longest sea-level record, Geophys. Res. Lett. 35, L22605. http://dx.doi.org/10.1029/2008GL035783.

Wöppelmann, G., Letetrel, C., Santamaria, A., Bouin, M.-N., Collilieux, X., Altamimi, Z., Williams, S.D.P., Miguez, B.M., 2009. Rates of sea-level change over the past century in a 
geocentric reference frame. Geophys. Res. Lett. 36, L12607. http://dx.doi.org/10.1029/2009GL038720.

Wöppelmann, G., Marcos, M., 2012. Coastal sea level rise in southern Europe and the nonclimate contribution of vertical land motion. J. Geophys. Res. 117, C01007. http://dx.doi.org/10.1029/2011JC007469. 